\title{
Push-Pull Stilbene: Visible Light Activated Photoremovable Protecting Group for Alcohols and Carboxylic Acids with Fluorescence Reporting Employed for Drug Delivery
}

Amrita Paul, Angana Biswas, Sreyashi Sinha, Sk. Sheriff Shah, Manoranjan Bera, Mahitosh Mandal and N. D. Pradeep Singh*

\begin{tabular}{|c|c|c|}
\hline Sl. No. & Contents & $\begin{array}{l}\text { Page } \\
\text { No }\end{array}$ \\
\hline 1. & General Experimental Techniques & 2 \\
\hline 2. & General procedure for the synthesis of caged stilbene (2a-e) & $2-4$ \\
\hline 3. & ${ }^{1} \mathrm{H}$ and ${ }^{13} \mathrm{C}$ NMR of the caged compounds & $4-9$ \\
\hline 4. & HRMS spectra of the caged compounds & $9-13$ \\
\hline 5. & Photophysical properties of caged stilbene (2a-e) & $13-15$ \\
\hline 6. & Measurement of fluorescence quantum yields & 15 \\
\hline 7. & $\begin{array}{l}\text { Determination of incident photon flux }\left(\mathrm{I}_{0}\right) \text { of the UV lamp by potassium } \\
\text { ferrioxalate actinometry }\end{array}$ & $15-16$ \\
\hline 8. & The photochemical rate constant determination for caged stilbene (2a-e) & 17 \\
\hline 9. & In Vitro Cytotoxicity assay & $16-17$ \\
\hline 10. & Table S2 Uncaging under different visible light source & 17 \\
\hline 11. & Table S3 Photochemical data of caged stilbene compounds (2a-e) & 18 \\
\hline 12. & Isolation of photoproduct 5 & 19 \\
\hline 13. & HRMS spectrum of photoproduct 5 & 19 \\
\hline 14. & Photolysis of caged stilbene $\mathbf{2 b}$ monitored by ${ }^{1} \mathrm{H}$ NMR in acetonitrile- $\mathrm{d}_{3}$ & 20 \\
\hline 15. & ${ }^{1} \mathrm{H}$ NMR spectrum of isolated photoproduct (5) & 20 \\
\hline 16. & Time dependent absorbance spectra for photorelease of $\mathbf{2 c}$ in acetonitrile & 21 \\
\hline 17. & Absorbance spectra for photorelease of $\mathbf{2 c}$ in different solvents & 21 \\
\hline 18. & $\begin{array}{l}\text { Uncaging of acid from cis caged stilbene (3d) under dark and light } \\
\text { conditions }\end{array}$ & 22 \\
\hline 19. & Kinetics of the dark release step & $22-23$ \\
\hline 20. & Hydrolytic stability of the caged stilbenes under dark (2a-e) & 23 \\
\hline 21. & RP-HPLC chromatograms of drug (cbl) release from the DDS (2e) & 24 \\
\hline 22. & Cellular viability assay & 24 \\
\hline
\end{tabular}




\section{General Experimental Techniques:}

All reagents were purchased from Sigma Aldrich and were used without further purification. Dimethyl sulfoxide and dichloromethane were distilled from $\mathrm{CaH}_{2}$ before use. ${ }^{1} \mathrm{H}$ NMR spectra were recorded on a BRUKER-AC 400-MHz spectrophotometer. Chemical shifts are reported in $\mathrm{ppm}$ from tetramethylsilane with the solvent resonance as the internal standard $\left(\mathrm{CDCl}_{3}: 7.26\right.$ $\mathrm{ppm})$. Data are reported as follows: chemical shifts, multiplicity $(\mathrm{s}=$ singlet, $\mathrm{d}=$ doublet, $\mathrm{t}=$ triplet, $\mathrm{m}=$ multiplet $)$, coupling constant $(\mathrm{Hz}) .{ }^{13} \mathrm{C}$ NMR $(100 \mathrm{MHz})$ spectra were recorded on a BRUKER- AC 400-MHz spectrometer with complete proton decoupling. Chemical shifts are reported in ppm from tetramethylsilane with the solvent resonance as the internal standard $\left(\mathrm{CDCl}_{3}: 77.0 \mathrm{ppm}\right)$. UV/Vis absorption spectra were recorded on a Shimadzu UV-2450 UV/ Vis spectrophotometer; fluorescence emission spectra were recorded on a Hitachi F-7000 fluorescence spectrophotometer HRMS spectra were recorded on a JEOL-AccuTOF JMST100L mass spectrometer. Photolysis of the caged compounds was carried out using 125-W medium-pressure Hg lamp supplied by SAIC (India). Chromatographic purification was done with 60-120-mesh silica gel (Merck). For reaction monitoring, precoated silica gel 60 F254 TLC sheets (Merck) were used. RP-HPLC was recorded using acetonitrile and water in the mobile phase, at a flow rate of $1 \mathrm{~mL} / \mathrm{min}$.

\section{General procedure for the synthesis of caged stilbene (2a-e).}

Potassium tert-butoxide (1.5 eq) was added to a dry THF solution (5 mL) of (4nitrobenzyl)triphenylphosphonium bromide (1.5 eq) in ice-water bath with stirring for $1 \mathrm{~h}$. After that O-protected 4-(diethylamino)-2-hydroxybenzaldehyde (1a-e) was added to the solution with stirring and refluxed at $70{ }^{\circ} \mathrm{C}$. Completion of the reaction was checked through TLC analysis. After completion of the reaction, parts of the solvents were evaporated in vacuo and the residue was dissolved in ethylacetate. $30 \mathrm{~mL}$ of water was then added to the ethylacetate solution, and the organic layer was purified by column chromatography on a silica gel column with 1:9 (EtOAc : PET ether) to give a crimson products (2a-e) in $75-82 \%$ yield.

\section{(E)-3-ethoxy-N,N-diethyl-4-(4-nitrostyryl)aniline (2a)}

Potassium tert-butoxide (174 $\mathrm{mg}, 1.55 \mathrm{mmol}$ ) was added to a dry THF solution ( $5 \mathrm{~mL}$ ) of (4nitrobenzyl)triphenylphosphonium bromide $(741 \mathrm{mg}, 1.55 \mathrm{mmol})$ in ice-water bath with stirring for $1 \mathrm{~h}$. After that 4-(diethylamino)-2-ethoxybenzaldehyde (1a) (200 mg, $1 \mathrm{mmol}$ ) was added to the solution with stirring and refluxed at $70{ }^{\circ} \mathrm{C}$. Completion of the reaction was checked through TLC analysis. After completion of the reaction, parts of the solvents were evaporated in vacuo and the residue was dissolved in ethylacetate and washed with $30 \mathrm{~mL}$ of 
water. The organic layer was purified by column chromatography on a silica gel column with 1:9 (EtOAc : PET ether) to give a crimson red solid product (2a) $(279 \mathrm{mg}, 0.82 \mathrm{mmol})$ with $82 \%$ yield. This compound was obtained in $(E) /(Z)$ mixture $((E)$-isomer/ $(Z)$-isomer $=9: 1)$

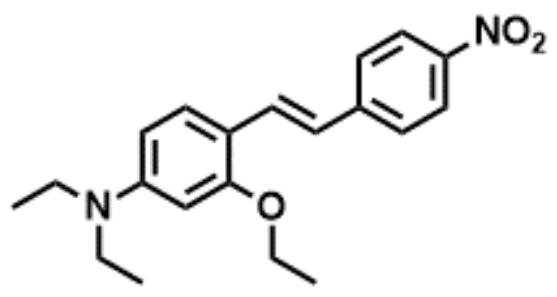

${ }^{1} \mathrm{H}$ NMR (400 MHz, Chloroform- $d$ ) $\delta 8.16(\mathrm{~d}, J=8.8 \mathrm{~Hz}$, 2H), $7.57(\mathrm{~d}, J=16.3 \mathrm{~Hz}, 1 \mathrm{H}), 7.54(\mathrm{~d}, J=8.8 \mathrm{~Hz}, 2 \mathrm{H})$, $7.44(\mathrm{~d}, J=8.7 \mathrm{~Hz}, 1 \mathrm{H}), 6.99(\mathrm{~d}, J=16.3 \mathrm{~Hz}, 1 \mathrm{H}), 6.31$ $(\mathrm{dd}, J=8.7,2.3 \mathrm{~Hz}, 1 \mathrm{H}), 6.16(\mathrm{~d}, J=2.6 \mathrm{~Hz}, 1 \mathrm{H}), 4.11(\mathrm{q}$, $J=6.9 \mathrm{~Hz}, 2 \mathrm{H}), 3.40(\mathrm{q}, J=7.0 \mathrm{~Hz}, 4 \mathrm{H}), 1.51(\mathrm{t}, J=6.9$

$\mathrm{Hz}, 4 \mathrm{H}), 1.20$ (t, $J=7.1 \mathrm{~Hz}, 6 \mathrm{H}) .{ }^{13} \mathrm{C}$ NMR (101 MHz, Chloroform- $d$ ) $\delta 158.6,156.4,149.6$, $146.3,129.1,128.4,125.9,124.1,121.1,104.6,100.0,95.4,63.9,44.6,14.9,12.7$. HR-MS calc for $\mathrm{C}_{20} \mathrm{H}_{24} \mathrm{~N}_{2} \mathrm{O}_{3}\left[\mathrm{MH}^{+}\right]$: 341.1860 , found: 341.1852 .

(E)-3-(benzyloxy)-N,N-diethyl-4-(4-nitrostyryl)aniline (2b)

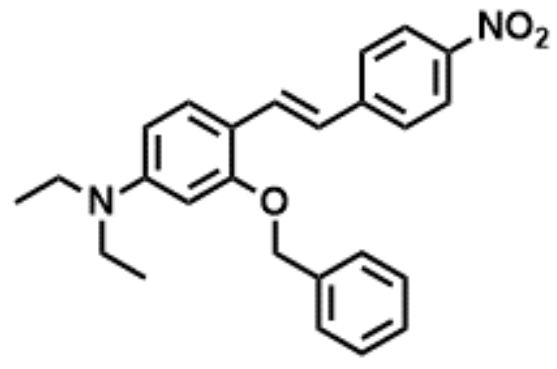

This was synthesised by same procedure using 2(benzyloxy)-4-(diethylamino)benzaldehyde (1b) (200 mg, $0.7 \mathrm{mmol}$ ) and (4-nitrobenzyl)triphenylphosphonium bromide, then purified by column chromatography on a silica gel column with 1:9 (EtOAc : PET ether) to give a crimson red solid product (2b) with $82 \%$ yield $(232 \mathrm{mg}$, $0.57 \mathrm{mmol}$. This compound was obtained in $(\mathrm{E}) /(\mathrm{Z})$ mixture $((\mathrm{E})$-isomer/(Z)-isomer $=9: 1) .{ }^{1} \mathrm{H}$ NMR (400 MHz, Chloroform-d) $\delta 8.14(\mathrm{~d}, J=8.8 \mathrm{~Hz}, 2 \mathrm{H}), 7.60(\mathrm{~d}, J=16.4 \mathrm{~Hz}, 1 \mathrm{H}), 7.56-$ $7.31(\mathrm{~m}, 8 \mathrm{H}), 7.00(\mathrm{~d}, J=16.3 \mathrm{~Hz}, 1 \mathrm{H}), 6.33(\mathrm{dd}, J=8.7,2.1 \mathrm{~Hz}, 1 \mathrm{H}), 6.21(\mathrm{~s}, 1 \mathrm{H}), 5.17$ (s, $2 \mathrm{H}), 3.35(\mathrm{q}, J=7.1 \mathrm{~Hz}, 4 \mathrm{H}), 1.14(\mathrm{t}, J=7.1 \mathrm{~Hz}, 6 \mathrm{H}) .{ }^{13} \mathrm{C}$ NMR $(101 \mathrm{MHz}$, Chloroform- $d) \delta$ $158.3,149.5,145.9,145.5,137.3,128.9,128.7,128.5,127.9,127.2,125.9,124.1,121.4,113.2$, 104.9, 96.3, 70.6, 44.6, 12.7.HR-MS calc for $\mathrm{C}_{25} \mathrm{H}_{26} \mathrm{~N}_{2} \mathrm{O}_{3}\left[\mathrm{MH}^{+}\right]$: 403.2016, found: 403.2013. (E)-5-(diethylamino)-2-(4-nitrostyryl)phenyl acetate (2c)

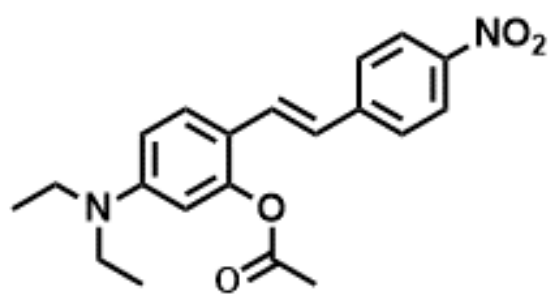

This was synthesised by same procedure using 5(diethylamino)-2-formylphenyl acetate (1c) $(200 \mathrm{mg}, 0.78$ mmol) and (4-nitrobenzyl)triphenylphosphonium bromide, then purified by column chromatography on a silica gel column with 1:9 (EtOAc: PET ether) to give a crimson red

solid product $(\mathbf{2 c})$ with $80 \%$ yield $(224 \mathrm{mg}, 0.63 \mathrm{mmol})$. This compound was obtained in $(\mathrm{E}) /(\mathrm{Z})$ mixture $((\mathrm{E})$-isomer/(Z)-isomer $=9.3: 0.7){ }^{1} \mathrm{H}$ NMR $(400 \mathrm{MHz}$, Chloroform- $d) \delta 8.18$ $(\mathrm{d}, J=8.8 \mathrm{~Hz}, 2 \mathrm{H}), 7.54(\mathrm{t}, J=9.4 \mathrm{~Hz}, 3 \mathrm{H}), 7.18(\mathrm{~d}, J=16.3 \mathrm{~Hz}, 1 \mathrm{H}), 6.91(\mathrm{~d}, J=16.2 \mathrm{~Hz}$, $1 \mathrm{H}), 6.58(\mathrm{dd}, J=8.9,2.5 \mathrm{~Hz}, 1 \mathrm{H}), 6.30(\mathrm{~d}, J=2.6 \mathrm{~Hz}, 1 \mathrm{H}), 3.38(\mathrm{q}, J=7.1 \mathrm{~Hz}, 4 \mathrm{H}), 2.40(\mathrm{~s}$, 
3H), $1.19(\mathrm{t}, J=7.1 \mathrm{~Hz}, 6 \mathrm{H}) .{ }^{13} \mathrm{C}$ NMR $(101 \mathrm{MHz}$, Chloroform- $d) \delta 169.4,150.3,149.1,146.0$, 144.9, 127.6, 126.9, 126.2, 122.9, 115.5, 109.8, 104.8, 100.0, 44.5, 21.1, 12.6. HR-MS calc for $\mathrm{C}_{20} \mathrm{H}_{22} \mathrm{~N}_{2} \mathrm{O}_{4}\left[\mathrm{MH}^{+}\right]: 355.1652$, found: 355.1648 .

(E)-5-(diethylamino)-2-(4-nitrostyryl)phenyl 4-methoxybenzoate (2d)

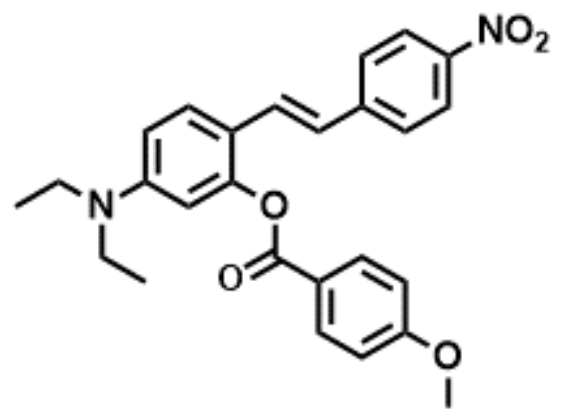

This was synthesised by same procedure using 5(diethylamino)-2-formylphenyl 4-methoxybenzoate (1d) (200 $\mathrm{mg}, \quad 0.61 \quad \mathrm{mmol}) \quad$ and $\quad$ (4nitrobenzyl)triphenylphosphonium bromide, then purified by column chromatography on a silica gel column with 1:9

(EtOAc : PET ether) to give a crimson red solid product (2d) with $78 \%$ yield $(212 \mathrm{mg}, 0.47 \mathrm{mmol})$. This compound was obtained in $(\mathrm{E}) /(\mathrm{Z})$ mixture $\left((\mathrm{E})\right.$-isomer/(Z)-isomer = 9.5:0.5). ${ }^{1} \mathrm{H}$ NMR $(400 \mathrm{MHz}$, Chloroform- $d) \delta 8.23(\mathrm{~d}, J=8.6 \mathrm{~Hz}$, $2 \mathrm{H}), 8.10(\mathrm{~d}, J=8.2 \mathrm{~Hz}, 2 \mathrm{H}), 7.68-7.55(\mathrm{~m}, 1 \mathrm{H}), 7.42(\mathrm{~d}, J=8.1 \mathrm{~Hz}, 2 \mathrm{H}), 7.24(\mathrm{~d}, J=16.2$ $\mathrm{Hz}, 1 \mathrm{H}), 7.05(\mathrm{~d}, J=8.4 \mathrm{~Hz}, 2 \mathrm{H}), 6.95(\mathrm{~d}, J=15.8 \mathrm{~Hz}, 1 \mathrm{H}), 6.62(\mathrm{~s}, 1 \mathrm{H}), 6.43(\mathrm{~s}, 1 \mathrm{H}), 3.93(\mathrm{~s}$, $3 \mathrm{H}), 3.45-3.33(\mathrm{~m}, 4 \mathrm{H}), 1.21(\mathrm{t}, J=5.8 \mathrm{~Hz}, 6 \mathrm{H}) .{ }^{13} \mathrm{C}$ NMR $(101 \mathrm{MHz}$, Chloroform- $d) \delta 164.8$, 164.1, 150.8, 149.2, 145.9, 144.9, 132.4, 127.7, 127.2, 126.1, 124.1, 122.7, 121.6, 115.8, 114.1, 109.8, 105.2, 55.6, 44.5, 12.6. HR-MS calc for $\mathrm{C}_{26} \mathrm{H}_{27} \mathrm{~N}_{2} \mathrm{O}_{5}\left[\mathrm{MH}^{+}\right]$: 447.1914, found: 447.1923.

(E)-5-(diethylamino)-2-(4-nitrostyryl)phenyl 4-chorambucil (2e)

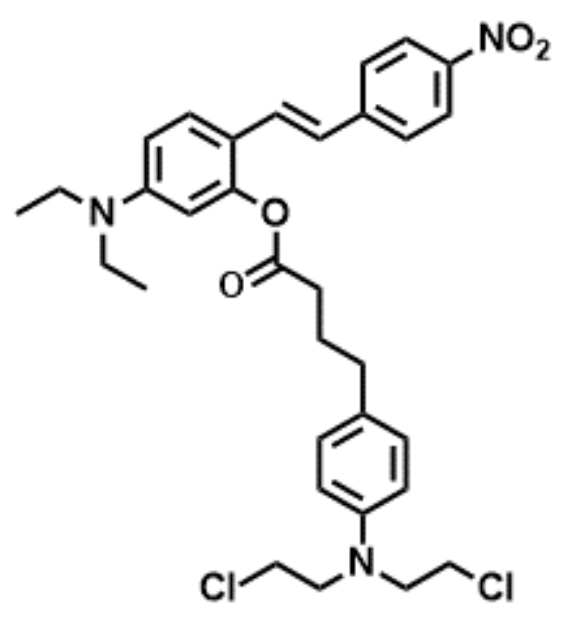

This was synthesised by same procedure using 2chlorambucil-4-(diethylamino)benzaldehyde (1e) (100 mg, $0.2 \mathrm{mmol}$ ) and (4-nitrobenzyl)triphenylphosphonium bromide, then purified by column chromatography on a silica gel column with 1:9 (EtOAc : PET ether) to give a crimson red solid product (2e) with $75 \%$ yield (94 $\mathrm{mg}, 0.15$ mmol. This compound was obtained in $(\mathrm{E}) /(\mathrm{Z})$ mixture ((E)-isomer/(Z)-isomer $=9.5: 0.5 .{ }^{1} \mathrm{H}$ NMR $(400 \mathrm{MHz}$, Chloroform-d) $\delta 8.09(\mathrm{~d}, \mathrm{~J}=8.3 \mathrm{~Hz}, 2 \mathrm{H}), 7.55(\mathrm{~d}, \mathrm{~J}=8.6$ $\mathrm{Hz}, 1 \mathrm{H}), 7.46(\mathrm{~d}, \mathrm{~J}=8.3 \mathrm{~Hz}, 2 \mathrm{H}), 7.19(\mathrm{~d}, \mathrm{~J}=16.2 \mathrm{~Hz}, 1 \mathrm{H}), 7.11(\mathrm{~d}, \mathrm{~J}=8.0 \mathrm{~Hz}, 2 \mathrm{H}), 6.90$ (d, $\mathrm{J}=16.2 \mathrm{~Hz}, 1 \mathrm{H}), 6.65(\mathrm{~d}, \mathrm{~J}=8.0 \mathrm{~Hz}, 2 \mathrm{H}), 6.61-6.53(\mathrm{~m}, 1 \mathrm{H}), 6.31(\mathrm{~s}, 1 \mathrm{H}), 3.72-3.63(\mathrm{~m}$, $8 \mathrm{H}), 3.38(\mathrm{q}, \mathrm{J}=6.7 \mathrm{~Hz}, 4 \mathrm{H}), 2.70(\mathrm{t}, \mathrm{J}=7.4 \mathrm{~Hz}, 4 \mathrm{H}), 2.16-2.09(\mathrm{~m}, 2 \mathrm{H}), 1.20(\mathrm{t}, \mathrm{J}=6.6 \mathrm{~Hz}$, $6 \mathrm{H}) .{ }^{13} \mathrm{C}$ NMR (101 MHz, Chloroform- $d$ ) $\delta 171.70,150.4,149.1,146.1,144.9,144.7,130.3$, 129.6, 127.6, 127.1, 1.16, 124.0, 123.0, 115.6, 112.5, 110.0, 105.25, 53.6, 44.7, 40.6, 34.1, 34.0, 27.1, 12.5. HR-MS calc for $\mathrm{C}_{32} \mathrm{H}_{38} \mathrm{Cl}_{2} \mathrm{~N}_{3} \mathrm{O}_{4}[\mathrm{MH}+]$ : 598.2234, found: 598.2249. 
3. ${ }^{1} \mathrm{H}$ and ${ }^{13} \mathrm{C}$ NMR of the caged compounds
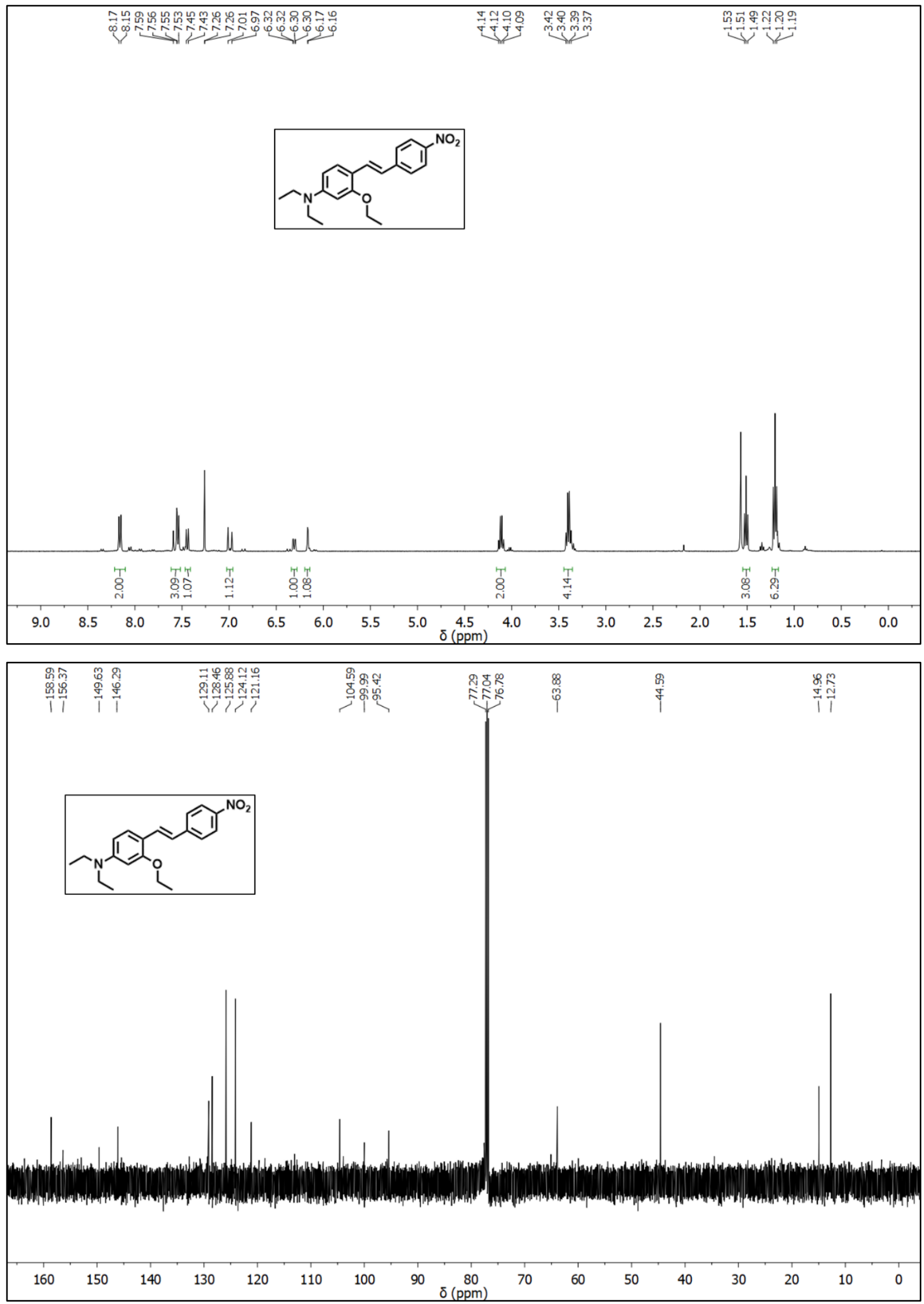

Figure S1. ${ }^{1} \mathrm{H}$ and ${ }^{13} \mathrm{C}$ NMR spectra of $\mathbf{2 a}$ in $\mathrm{CDCl}_{3}$. 


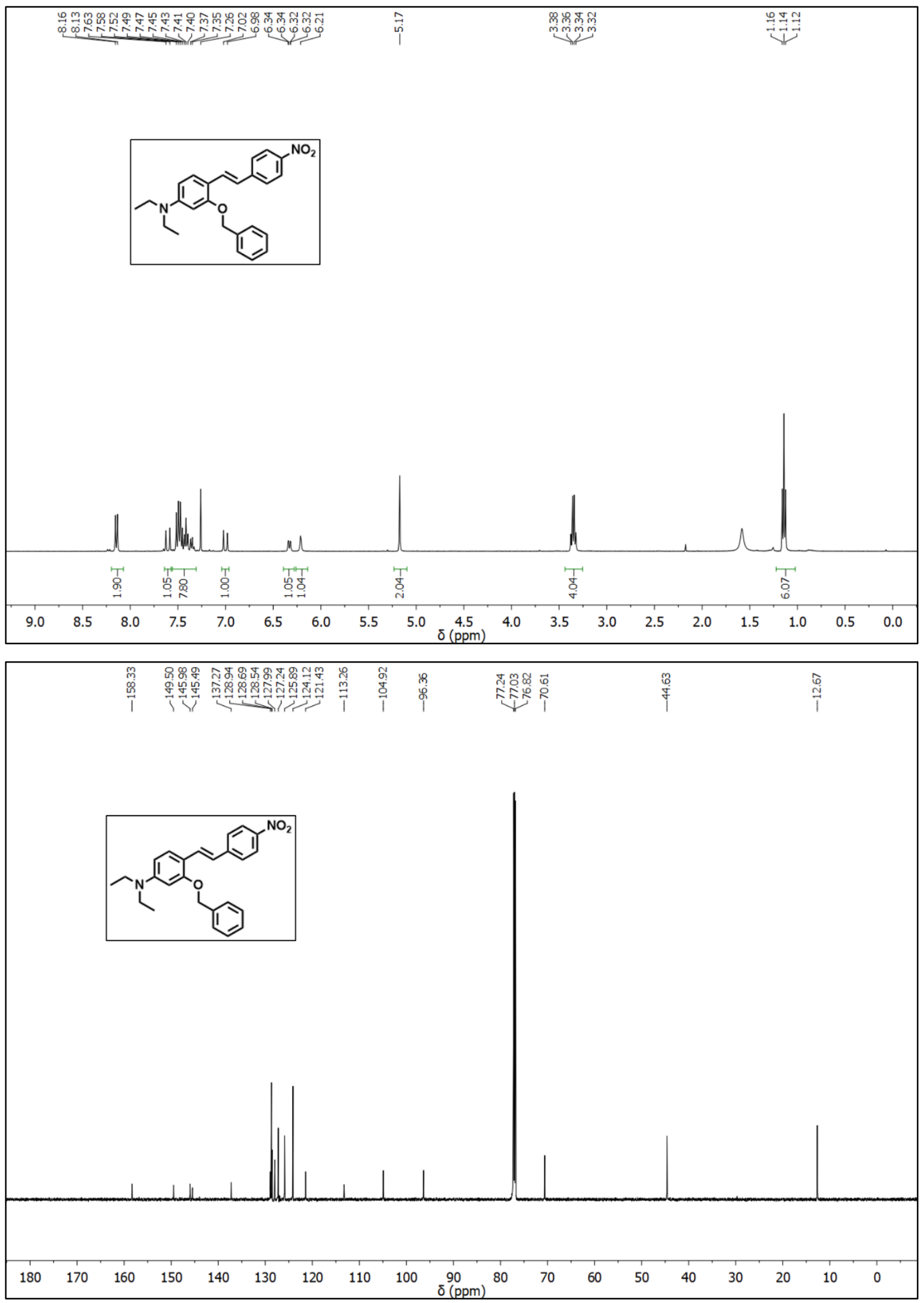

Figure S2. ${ }^{1} \mathrm{H}$ and ${ }^{13} \mathrm{C}$ NMR spectra of $\mathbf{2 b}$ in $\mathrm{CDCl}_{3}$. 

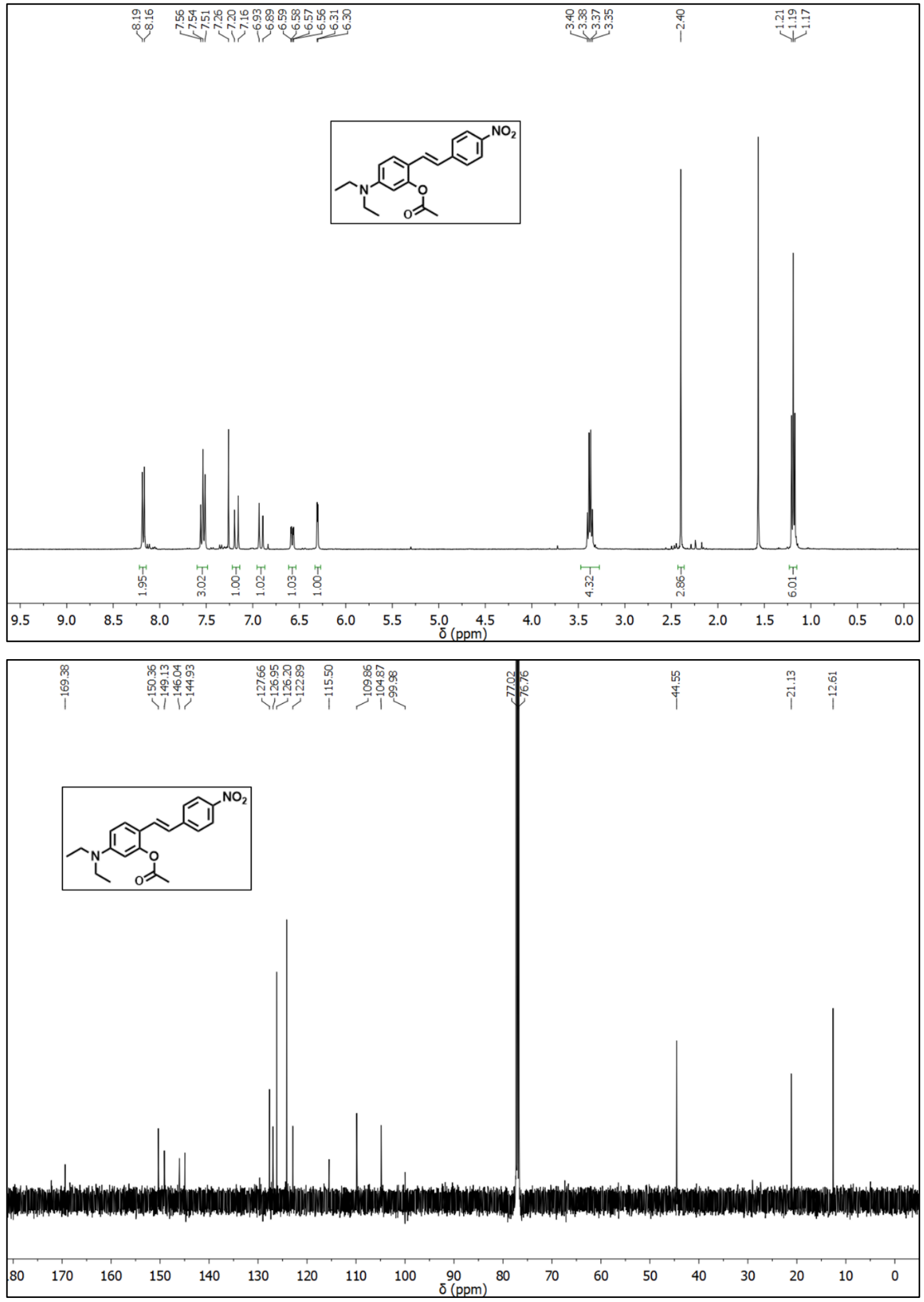

Figure S3. ${ }^{1} \mathrm{H}$ and ${ }^{13} \mathrm{C}$ NMR spectra of $2 \mathrm{c}$ in $\mathrm{CDCl}_{3}$. 

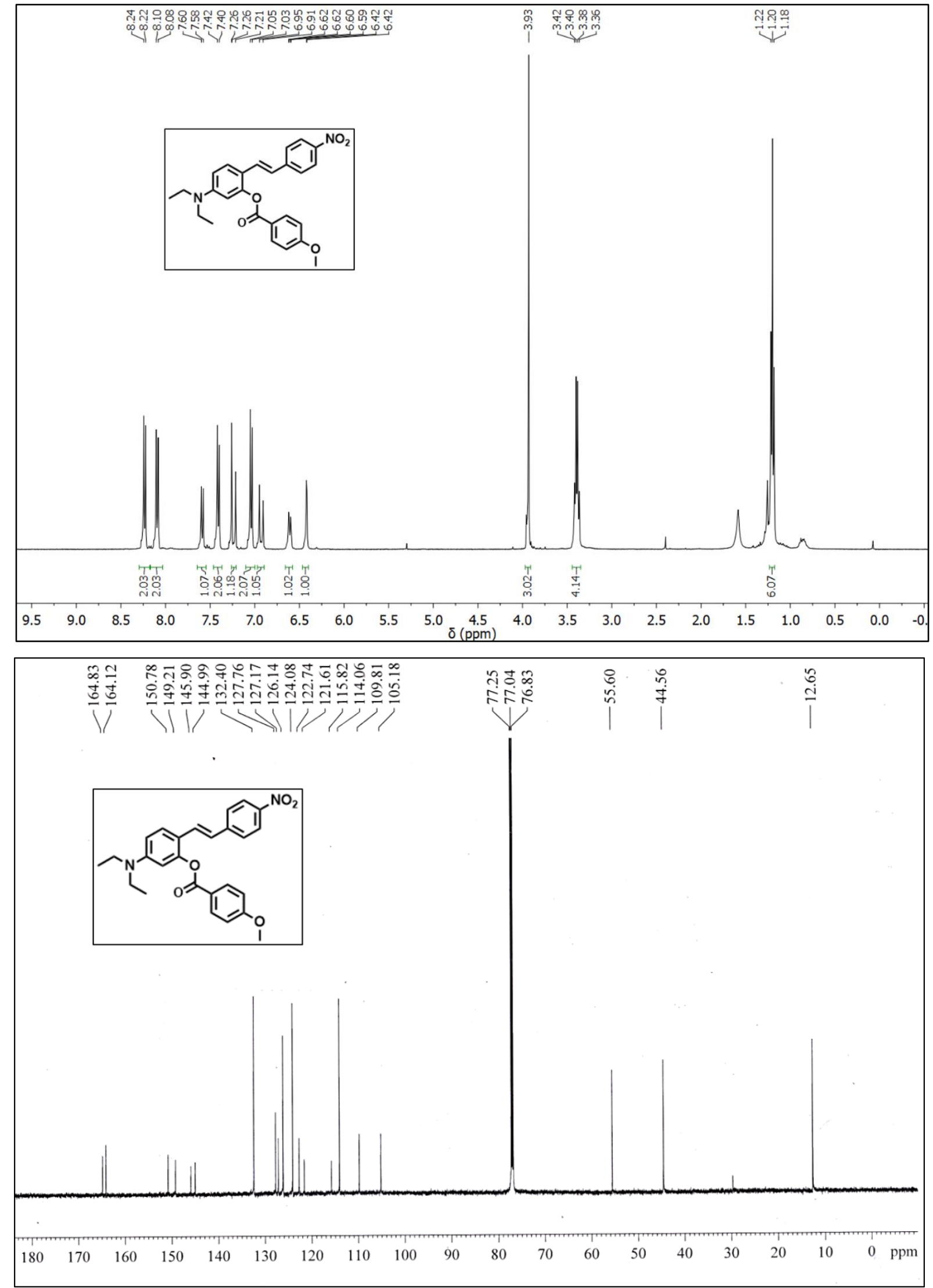

Figure S4. ${ }^{1} \mathrm{H}$ and ${ }^{13} \mathrm{C}$ NMR spectra of $\mathbf{2 d}$ in $\mathrm{CDCl}_{3}$. 

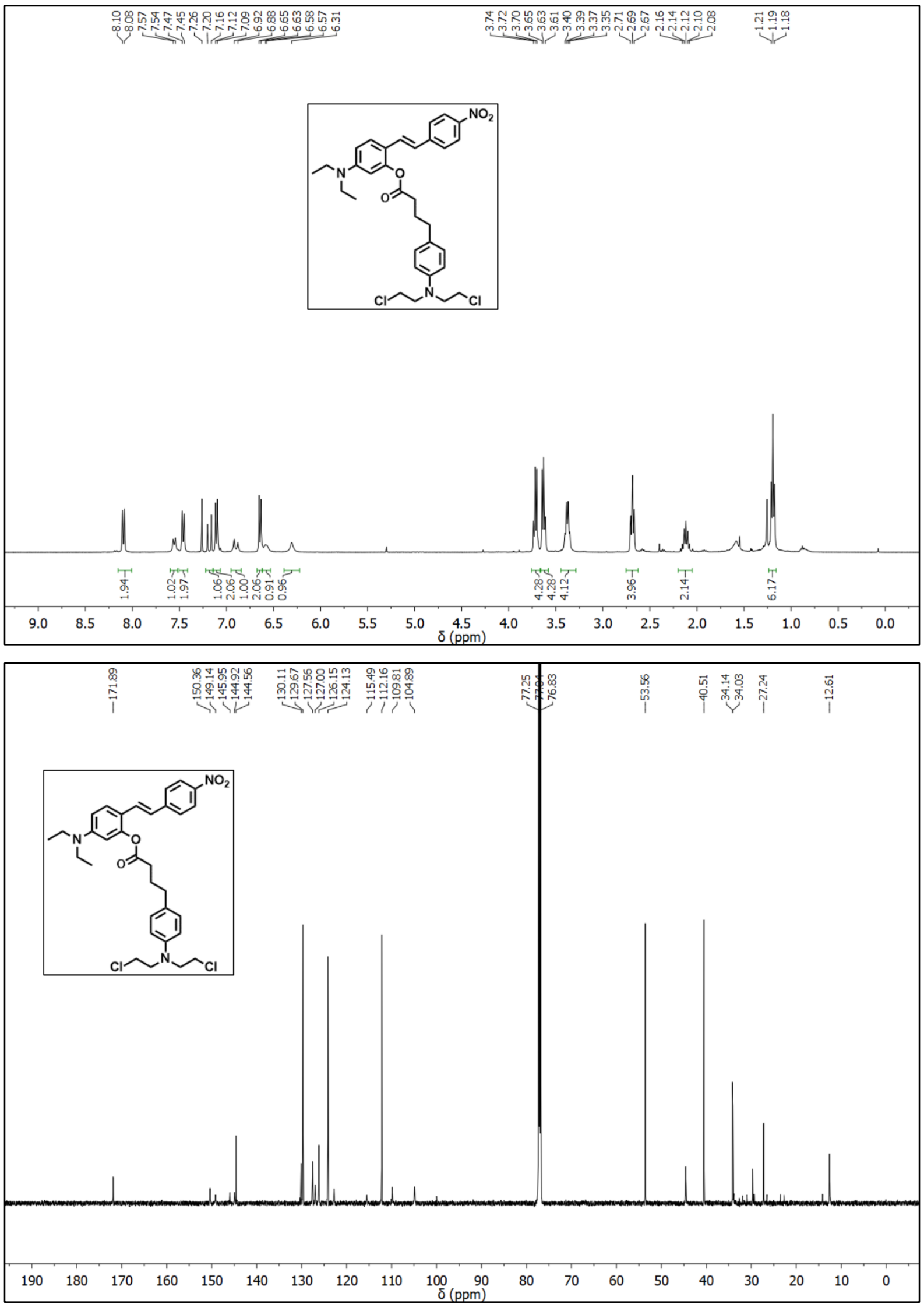

Figure S5. ${ }^{1} \mathrm{H}$ and ${ }^{13} \mathrm{C}$ NMR spectra of $2 \mathbf{e}$ in $\mathrm{CDCl}_{3}$. 


\section{HRMS spectrum of caged compounds}

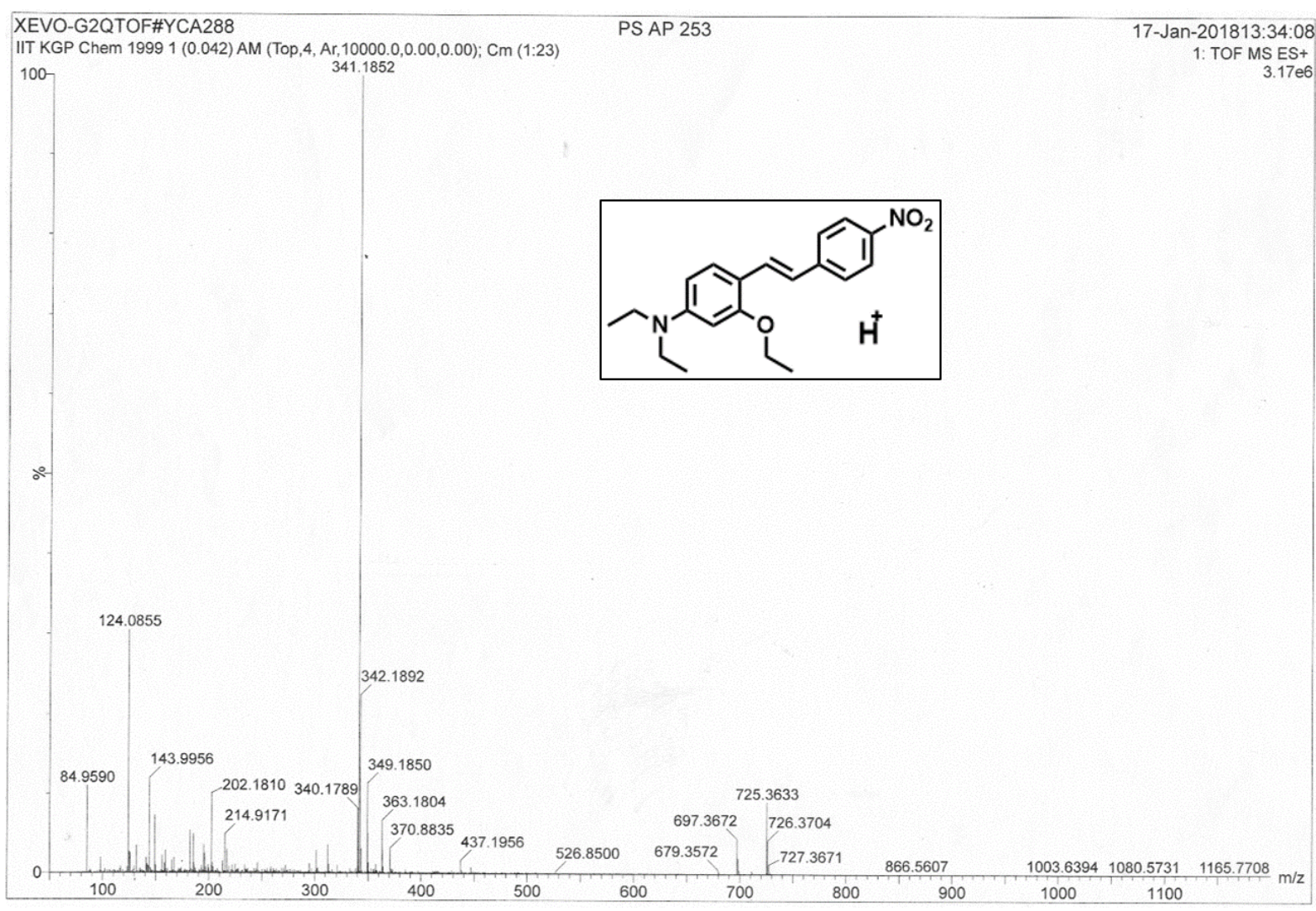

Figure S6. HRMS spectrum of 2a.

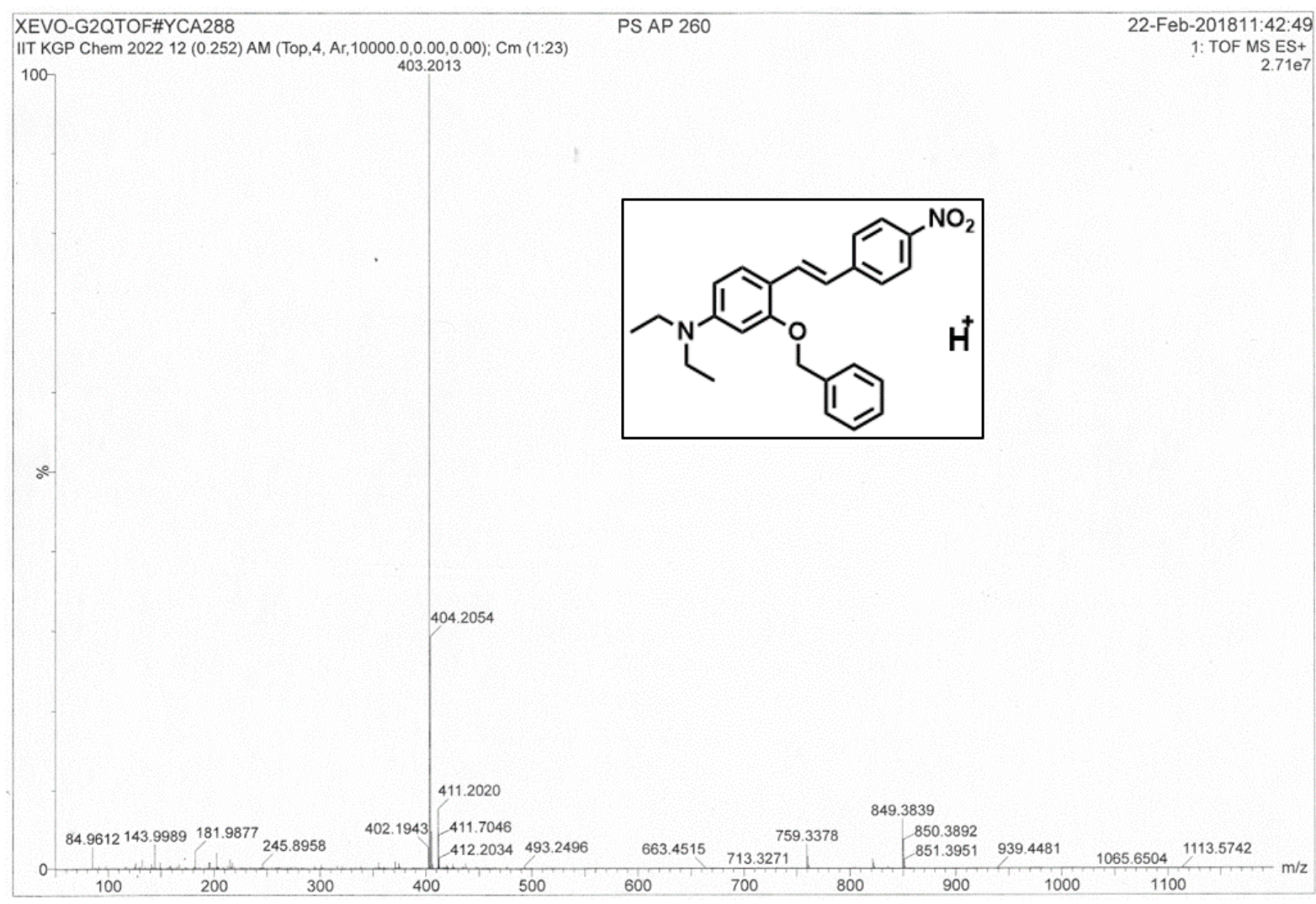

Figure S7. HRMS spectrum of $\mathbf{2 b}$. 


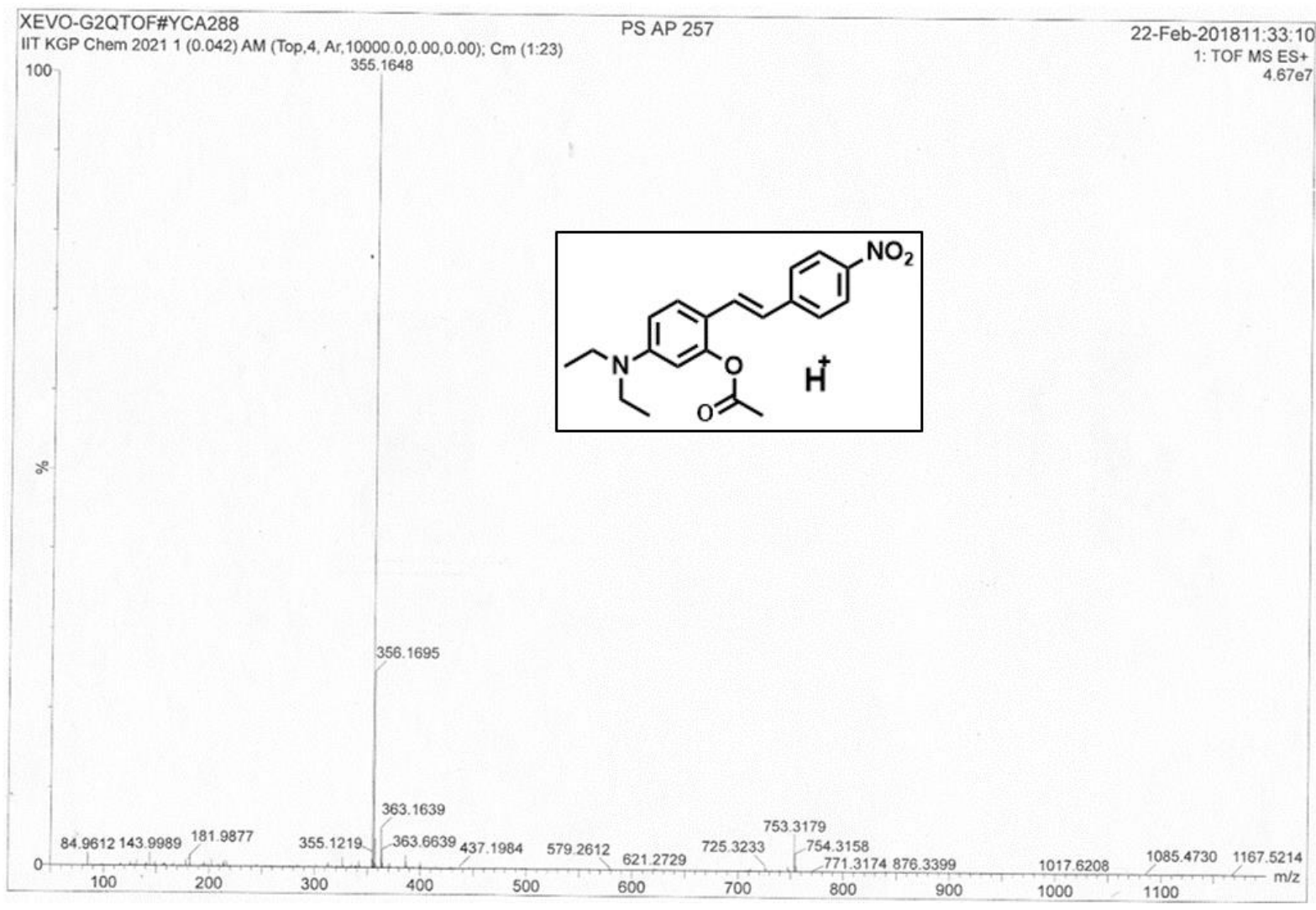

Figure S8. HRMS spectrum of 2 c. 


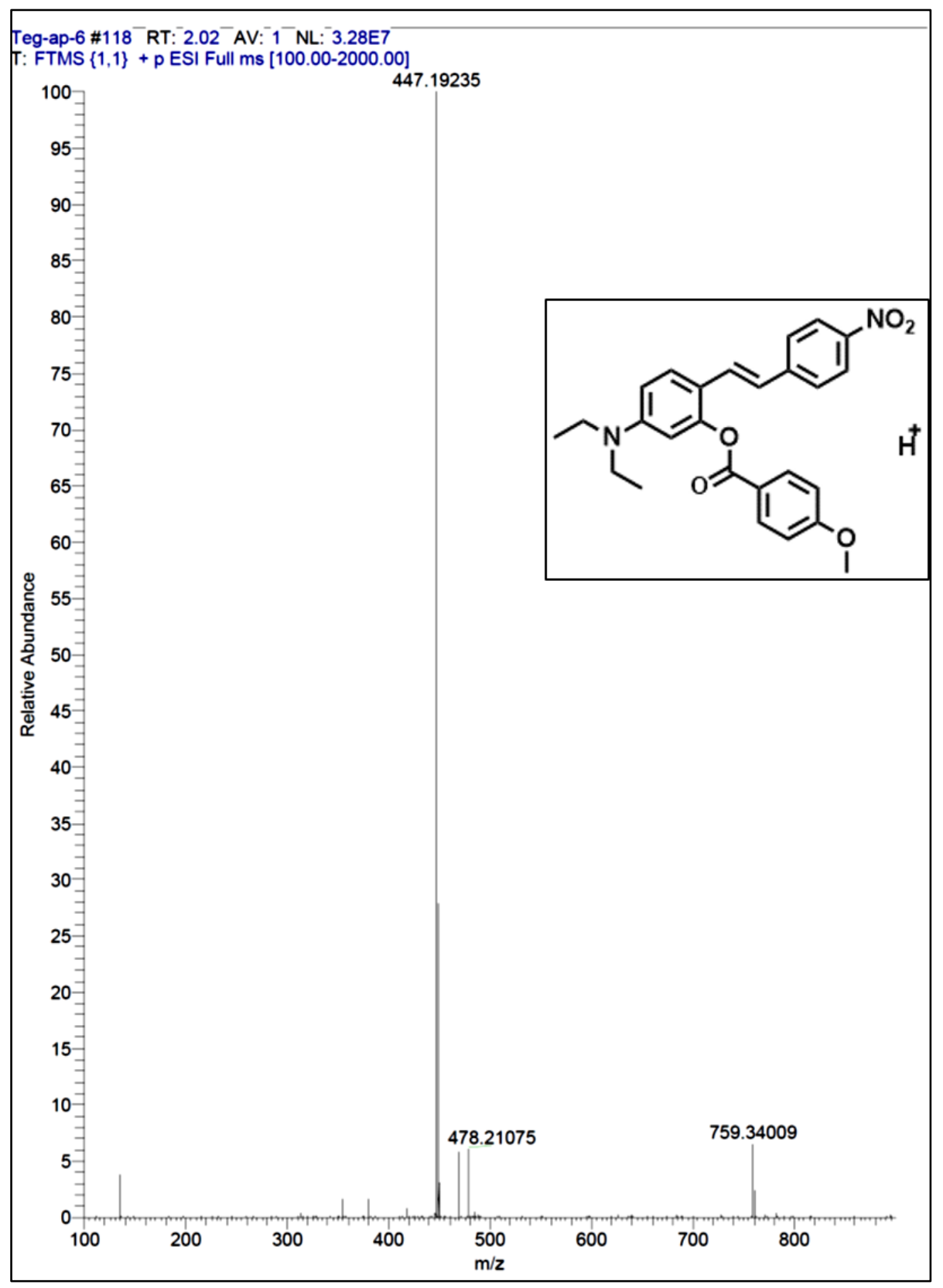

Figure S9. HRMS spectrum of $\mathbf{2 d}$. 


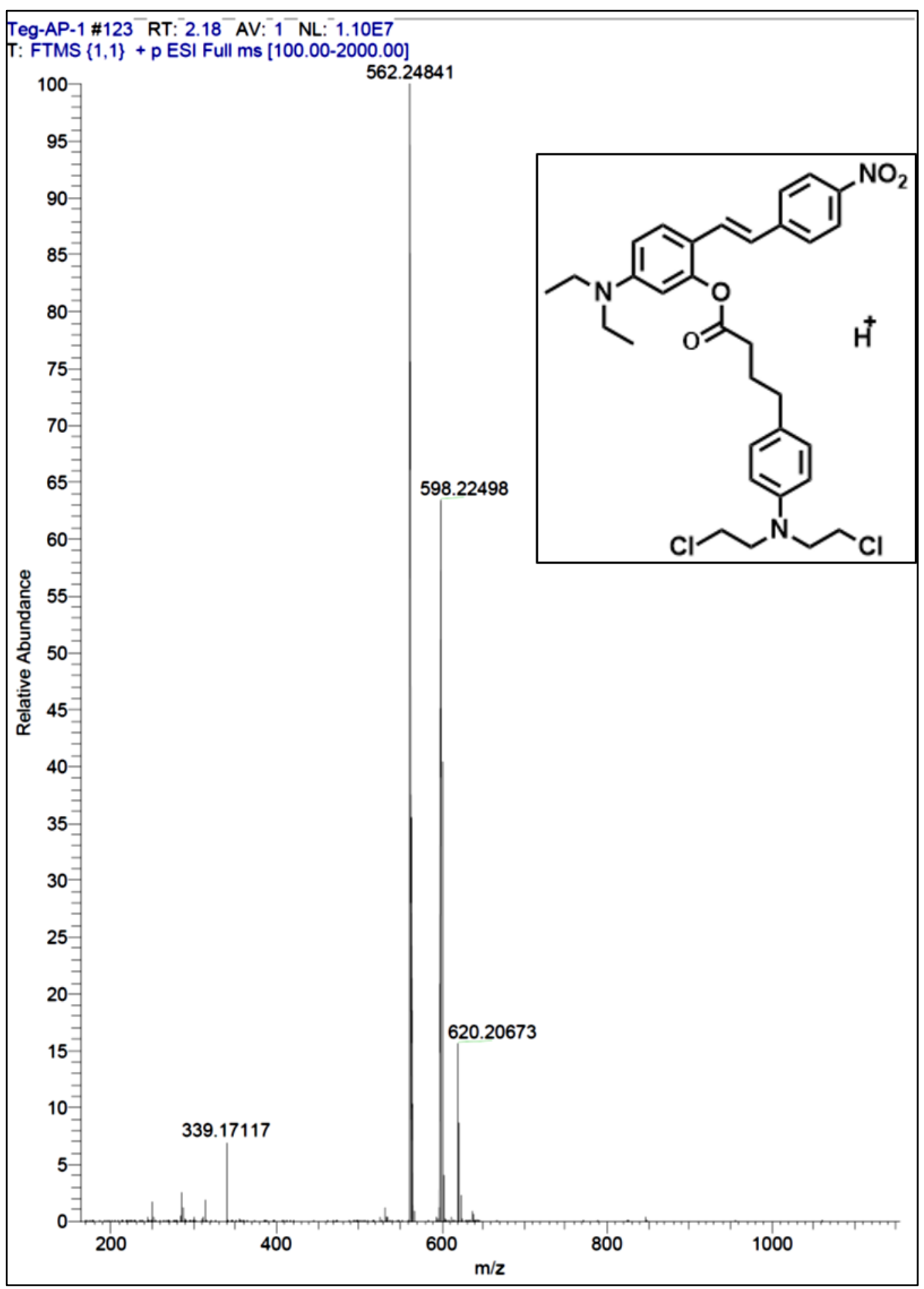

Figure S10. HRMS spectrum of 2e.

\section{Photophysical properties of caged stilbene (2a-e):}

The absorption and emission spectra of a degassed solution of caged stilbene $(2 \mathbf{a}-\mathbf{e})\left(1 \times 10^{-5}\right.$ $\mathrm{M}$ ) in different solvents were recorded on a UV-vis spectrophotometer and fluorescence spectrophotometer respectively.

Table S1. Photophysical data for the caged stilbene (2a-e) 


\begin{tabular}{|c|c|c|c|c|c|c|}
\hline $\begin{array}{c}\text { caged } \\
\text { stilbenes }\end{array}$ & solvents & $\lambda \max (\mathrm{nm})$ & $\lambda_{\mathrm{f}}(\mathrm{nm})$ & $\begin{array}{c}\text { stokes shift } \\
\text { (nm) }\end{array}$ & $\begin{array}{c}\varepsilon_{\max } \mathbf{x}^{10^{3}} \\
\left(\operatorname{lmol}^{-1} \mathbf{c m}^{-1}\right)\end{array}$ & $\phi_{f}$ \\
\hline \multirow[t]{7}{*}{$2 a$} & Hexane & 420 & 502 & 82 & 25.3 & 0.53 \\
\hline & Benzene & 428 & 572 & 144 & 24.7 & 0.32 \\
\hline & Chloroform & 427 & 672 & 245 & 29.3 & 0.03 \\
\hline & Ethylacetate & 428 & 635 & 207 & 29.6 & 0.25 \\
\hline & Methanol & 451 & 715 & 264 & 27.2 & 0.003 \\
\hline & Acetonitrile & 456 & 720 & 264 & 28.2 & $<0.002$ \\
\hline & THF & 455 & 642 & 187 & 28.4 & 0.12 \\
\hline \multirow[t]{7}{*}{$2 b$} & Hexane & 423 & 502 & 79 & 26.8 & 0.54 \\
\hline & Benzene & 431 & 572 & 141 & 23.7 & 0.31 \\
\hline & Chloroform & 430 & 672 & 242 & 27.3 & 0.04 \\
\hline & Ethylacetate & 430 & 635 & 205 & 28.6 & 0.26 \\
\hline & Methanol & 453 & 715 & 262 & 27.7 & 0.004 \\
\hline & Acetonitrile & 458 & 720 & 262 & 28.2 & $<0.002$ \\
\hline & THF & 457 & 642 & 185 & 28.4 & 0.12 \\
\hline \multirow[t]{7}{*}{$2 c$} & Hexane & 413 & 502 & 89 & 26.3 & 0.55 \\
\hline & Benzene & 425 & 572 & 147 & 23.7 & 0.33 \\
\hline & Chloroform & 427 & 672 & 245 & 28.3 & 0.03 \\
\hline & Ethylacetate & 429 & 635 & 206 & 29.6 & 0.26 \\
\hline & Methanol & 433 & 715 & 282 & 28.2 & 0.005 \\
\hline & Acetonitrile & 431 & 720 & 289 & 29.2 & $<0.002$ \\
\hline & THF & 432 & 642 & 210 & 28.4 & 0.11 \\
\hline \multirow[t]{5}{*}{$2 d$} & Hexane & 413 & 502 & 89 & 26.3 & 0.55 \\
\hline & Benzene & 424 & 572 & 148 & 23.7 & 0.33 \\
\hline & Chloroform & 428 & 672 & 244 & 28.3 & 0.03 \\
\hline & Ethylacetate & 429 & 635 & 206 & 29.6 & 0.26 \\
\hline & Methanol & 434 & 715 & 281 & 28.2 & 0.005 \\
\hline
\end{tabular}




\begin{tabular}{c|cccccc} 
Acetonitrile & 432 & 720 & 288 & 29.2 & $<0.002$ \\
THF & 431 & 642 & 211 & 28.4 & 0.11 \\
Hexane & 412 & 502 & 90 & 26.3 & 0.55 \\
Benzene & 426 & 572 & 146 & 23.7 & 0.33 \\
Chloroform & 428 & 672 & 244 & 28.3 & 0.03 \\
Ethylacetate & 431 & 635 & 204 & 29.6 & 0.26 \\
Methanol & 433 & 715 & 282 & 28.2 & 0.005 \\
Acetonitrile & 433 & 720 & 287 & 29.2 & $<0.002$ \\
THF & 430 & 642 & 212 & 28.4 & 0.11
\end{tabular}

Quantum Yield $\left(\Phi_{\mathrm{f}}\right.$ : Error limit within $\pm 10 \%$

\section{Measurement of fluorescence quantum yields}

The fluorescence quantum yield (QY) of the caged stilbene (2a-e) were determined by reference point method. ${ }^{1} \mathrm{~A} \mathrm{~N}_{2}$-outgassed solution of coumarin $334\left(\Phi_{\mathrm{f}}=0.69 \text { in methanol }\right)^{2}$ was used as standard for the fluorescence quantum yield determinations of compounds under $\mathrm{N}_{2}$-outgassed solutions with solvent refractive index correction. An error of $10 \%$ is estimated for the fluorescence quantum yields. The absorbance values of the solutions at the excitation wavelength were measured with UV-Vis spectrophotometer. Photoluminescence (PL) emission spectra of all the sample solutions were recorded by Hitachi F-7000 fluorescence spectrophotometer at respective excitation wavelength of compounds (2a-e).

$$
\frac{\phi s}{\phi R}=\frac{A s}{A_{R}} \frac{(\mathrm{Abs})_{\mathrm{R}}}{(\mathrm{Abs})_{\mathrm{S}}} \frac{\eta_{\mathrm{s}^{2}}}{\eta_{\mathrm{R}^{2}}}
$$

Where $\boldsymbol{\Phi}$ represents quantum yield, Abs represents absorbance, $\mathbf{A}$ represents area under the fluorescence curve, and $\boldsymbol{\eta}$ is refractive index of the medium. The subscripts $\mathbf{S}$ and $\mathbf{R}$ denote the corresponding parameters for the sample and reference, respectively.

\section{Determination of incident photon flux ( $\left.I_{0}\right)$ of the UV lamp by potassium ferrioxalate actinometry:}

Potassium ferrioxalate actinometry was used for the determination of incident photon flux ( $\left.\mathrm{I}_{0}\right)$ of the UV lamp used for irradiation. Solution of potassium ferrioxalate, 1,10- phenanthroline and the buffer solution were prepared following the literature procedure. ${ }^{3} 0.006 \mathrm{M}$ solution of potassium ferrioxalate was irradiated using $125 \mathrm{~W}$ medium pressure $\mathrm{Hg}$ lamp with $1 \mathrm{M} \mathrm{NaNO}_{2}$ 
solution (UV cut-off filter), as visible light source ( $\geq 410 \mathrm{~nm}$ ). At regular interval of time (3 $\min ), 1 \mathrm{~mL}$ of the aliquots was taken out and to it $3 \mathrm{~mL}$ of 1,10-phenanthroline solution and 2 $\mathrm{mL}$ of the buffer solution were added and the whole solution was kept in dark for $30 \mathrm{~min}$. The absorbance of red phenanthroline-ferrous complex formed was then measured spectrophotometrically at $510 \mathrm{~nm}$. The amount of $\mathrm{Fe}^{2+}$ ion was determined from the calibration graph. The calibration graph was plotted by measuring the absorbance of phenanthrolineferrous complex at several known concentration of $\mathrm{Fe}^{2+}$ ion in dark. From the slope of the graph the molar absorptivity of the phenanthroline-ferrous complex was calculated to be $1.10 \times 10^{4}$ $\mathrm{M}^{-1} \mathrm{~cm}^{-1}$ at $510 \mathrm{~nm}$ which is found to be similar to reported value. Using the known quantum yield $(1.188 \pm 0.012)$ for potassium ferrioxalate actinometer at $406.7 \mathrm{~nm}$, the number of $\mathrm{Fe}^{2+}$ ion formed during photolysis and the fraction of light absorbed by the actinometer, the incident intensity ( $\left.\mathrm{I}_{0}\right)$ of the $125 \mathrm{~W} \mathrm{Hg}$ lamp was determined as $2.886 \times 10^{16}$ quanta $^{-1}$.

\section{Photochemical rate constant determination for the photodegradation of caged stilbene} (2a-e):

A $20 \mathrm{~mL}$ solution of caged stilbene $(\mathbf{2 a - e})\left(1 \times 10^{-4} \mathbf{M}\right)$ was prepared in acetonitrile. Nitrogen was passed throughout the solution for $30 \mathrm{~min}$ and irradiated using $125 \mathrm{~W}$ medium pressure $\mathrm{Hg}$ lamp with $1 \mathrm{M} \mathrm{NaNO} 2$ solution as $\mathrm{UV}$ cut-off filter $(\lambda \geq 410 \mathrm{~nm})$. At regular interval of time, $20 \mu \mathrm{l}$ of the aliquots was taken and analyzed by RP-HPLC using mobile phase acetonitrile, at a flow rate of $1 \mathrm{~mL} / \mathrm{min}$ (detection: UV $254 \mathrm{~nm}$ ). Peak areas were determined by RP-HPLC, which indicated gradual decrease of the caged compound with time, and the average of three runs. The reaction was followed until the peak area of the caged stilbenes are less than $5 \%$ of the initial area. Based on HPLC data for caged compound, the natural logarithm of the concentration of caged compound ( $\operatorname{lnC}$ ) (from HPLC peak area) versus irradiation time was plotted. We observed an exponential correlation for the disappearance of the caged compounds which suggested a first order reaction. Further, the quantum yield for the photolysis of caged compound was calculated using equation (1)

$(\Phi)_{\mathrm{CG}}=(\Phi)_{\mathrm{act}} \times\left[\left(k_{p}\right)_{\mathrm{CG}} /\left(k_{p}\right)_{\mathrm{act}}\right] \times\left[\mathrm{Fact}_{\mathrm{ac}} / \mathrm{F}_{\mathrm{CG}}\right]$

Where, the subscript 'CG' and 'act' denote caged compound and actinometer, respectively. $\Phi$ is the relative photolysis quantum yield, $k_{p}$ is the photolysis rate constant and $\mathrm{F}$ is the fraction of light absorbed. Potassium ferrioxalate was used as an actinometer.

\section{In Vitro Cytotoxicity assay}

The cytotoxicity of caged stilbene (2a), DDS (2e) and free drug (cbl) was determined before and after irradiation in MCF-7 breast cancer cell line MTT assay. ${ }^{4} \mathrm{MCF}-7$ breast cancer cell 
line $\left(1 \times 10^{5}\right.$ cells/well of a 96 -well plate $)$ were treated for $48 \mathrm{~h}$ with different concentrations $\left(0.1-250 \mu \mathrm{g} \mathrm{mL}^{-1}\right)$ and cell viability was determined by MTT assay (Mossman, 1983), measuring absorbance at $595 \mathrm{~nm}$ using a micro plate reader (Bio-Rad 550). Cell viability was calculated using the formula, Viability $(\%)=100 \times \mathrm{A}_{2} / \mathrm{A}_{1}$; [Where $\mathrm{A}_{2}=$ Absorbance of the treated cell; $\mathrm{A}_{1}=$ Absorbance of the control cells].

Briefly, cells in exponential growth phase were trypsinised and seeded in 96-well culture plates $\left(1 \times 10^{5}\right.$ cells/well). After $12 \mathrm{~h}$ of cell seeding, the medium was replaced with a fresh complete medium (DMEM) containing $250 \mu \mathrm{g} \mathrm{mL}^{-1}$ of caged stilbene DDS (2e) and free drug (2a), (cbl) and was kept for $4 \mathrm{~h}$ at $37{ }^{\circ} \mathrm{C}$ in a $\mathrm{CO}_{2}$ incubator. Treated cells were irradiated with visible light $(\geq 410 \mathrm{~nm}$ ) for $0-20 \mathrm{~min}$.

\section{Table S2 Uncaging under different visible light sources}

\begin{tabular}{lll} 
caged stilbenes & $\mathbf{4 1 0} \mathbf{~ n m}$ & CFL lamp \\
\cline { 2 - 3 } & \% of & \% of \\
\hline $\mathbf{2 a}$ & uncaging $^{\mathbf{a}}$ & uncaging $^{\mathbf{b}}$ \\
$\mathbf{2 b}$ & 90 & 85 \\
$\mathbf{2 c}$ & 88 & 82 \\
$\mathbf{2 d}$ & 93 & 87 \\
$\mathbf{2 e}$ & 89 & 80 \\
\hline
\end{tabular}

$\%$ of uncaging from caged stilbenes was determined by RP-HPLC, ${ }^{\mathrm{a}}$ after $1 \mathrm{~h}$ irradiation under $125 \mathrm{~W}$ medium pressure $\mathrm{Hg}$ lamp with $1 \mathrm{M} \mathrm{NaNO}_{2}$ solution (UV cut-off filter) as the visible light source $(\lambda \geq 410 \mathrm{~nm}) .{ }^{\mathrm{b}} \mathrm{After} 6$ $\mathrm{h}$ irradiation under $23 \mathrm{~W}$ CFL lamp. 
11. Table S3 Photochemical data of caged stilbene compounds (2a-e)

\begin{tabular}{|c|c|c|c|}
\hline \multirow{2}{*}{$\begin{array}{c}\text { caged } \\
\text { stilbenes }\end{array}$} & \multicolumn{3}{|c|}{$\geq 410 \mathrm{~nm}$} \\
\hline & $\begin{array}{c}\% \text { of } \\
\text { uncaging }^{\mathrm{a}}\end{array}$ & $\begin{array}{l}\text { photochemical quantum } \\
\text { yield of decomposition } \\
\text { of starting material } \\
\left(\phi_{p}\right)^{b}\end{array}$ & $\begin{array}{l}\text { quantum yield of } \\
\text { formation } \\
\text { phenanthrene }^{c}\end{array}$ \\
\hline $2 \mathbf{a}$ & 90 & 0.12 & 0.05 \\
\hline $2 b$ & 88 & 0.11 & 0.04 \\
\hline $2 c$ & 93 & 0.14 & 0.06 \\
\hline $2 d$ & 89 & 0.10 & 0.04 \\
\hline $2 e$ & 90 & 0.10 & 0.03 \\
\hline
\end{tabular}

a $\%$ of uncaging from caged stilbenes was determined by RP-HPLC, ${ }^{b}$ photochemical quantum yield of decomposition of starting material, $\Phi_{\mathrm{p}}$ calculated using potassium ferrioxalate as an actinometer (error limit: $\pm 5 \%$ ), ${ }^{\mathrm{c}}$ quantum yield of formation of phenanthrene was determined by RP-HPLC using potassium ferrioxalate as an actinometer (error limit: $\pm 5 \%$ ) after $1 \mathrm{~h}$ irradiation under $125 \mathrm{~W}$ medium pressure $\mathrm{Hg}$ lamp with $1 \mathrm{M} \mathrm{NaNO}_{2}$ solution (UV cut-off filter) as the visible light source $(\lambda \geq 410 \mathrm{~nm})$.

\section{Isolation of the photoproduct}

Caged stilbene 2a (12 mg, $0.035 \mathrm{mmol})$ was dissolved in $50 \mathrm{~mL}$ degassed acetonitrile and photolysed under $125 \mathrm{~W}$ medium pressure $\mathrm{Hg}$ lamp with $1 \mathrm{M} \mathrm{NaNO} 2$ solution (UV cut-off filter) as the visible light source $(\lambda \geq 410 \mathrm{~nm})$ in nitrogen atmosphere. Completion of the photolysis was determined by TLC. Finally fter completion of the photolysis the solvent was removed in vacuum. The residue was purified by preparative layer chromatography (PLC) on a silica gel with 1:9 (EtOAc : PET ether) to give a yellow product (5) with $59 \%$ yield (6.1 mg, $0.021 \mathrm{mmol}$ ). The purity of the photoproduct was confirmed with RP-HPLC analysis with acetonitrile/water (9:1) as the mobile phase at a constant flow rate $\left(1 \mathrm{mLmin}^{-1}\right)$ which gave a peak at $t_{R}=3.41 \min ($ Figure S11). 


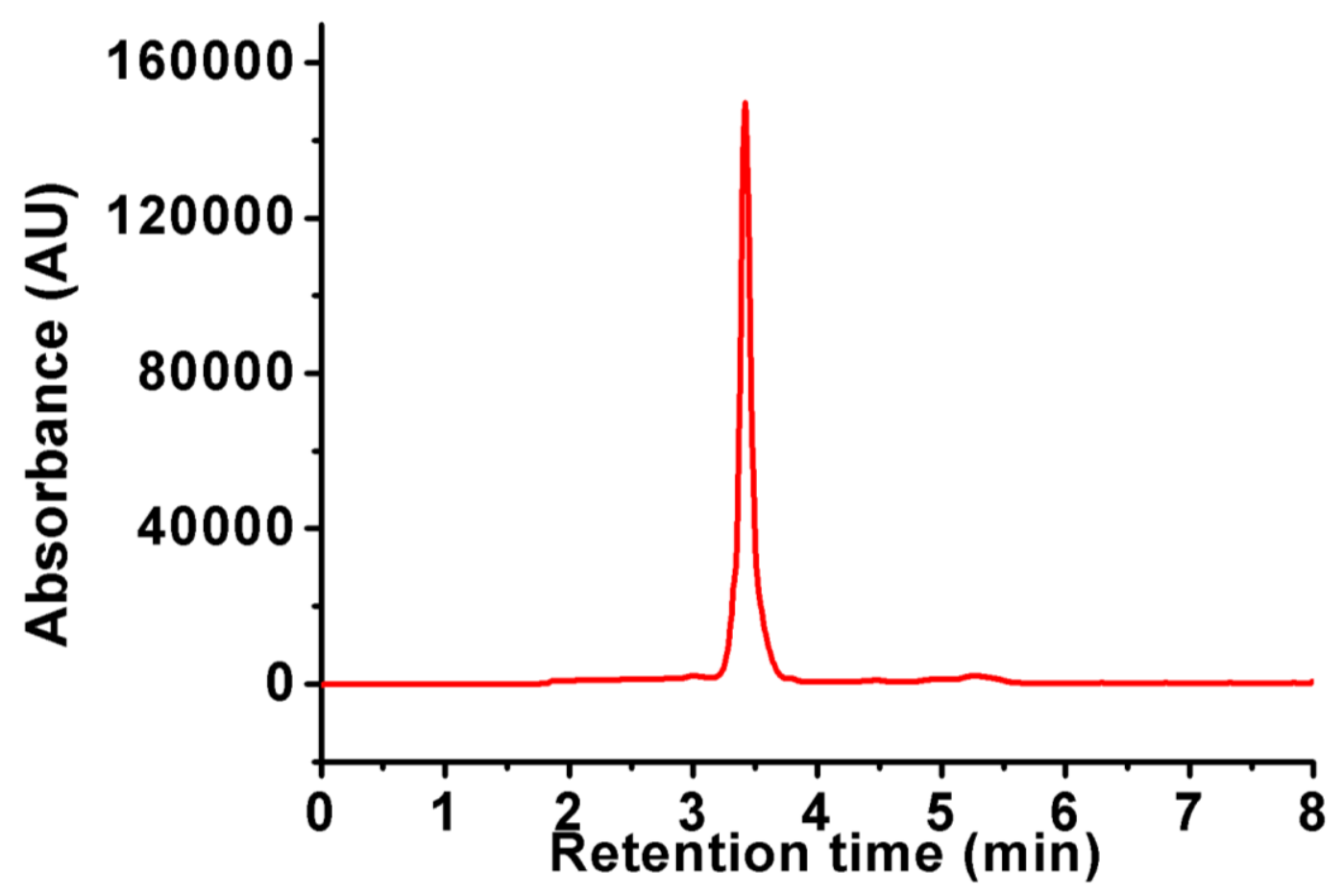

Figure S11: RP-HPLC chromatogram of the isolated photoproduct 5.

13. HRMS spectrum of photoproduct 5

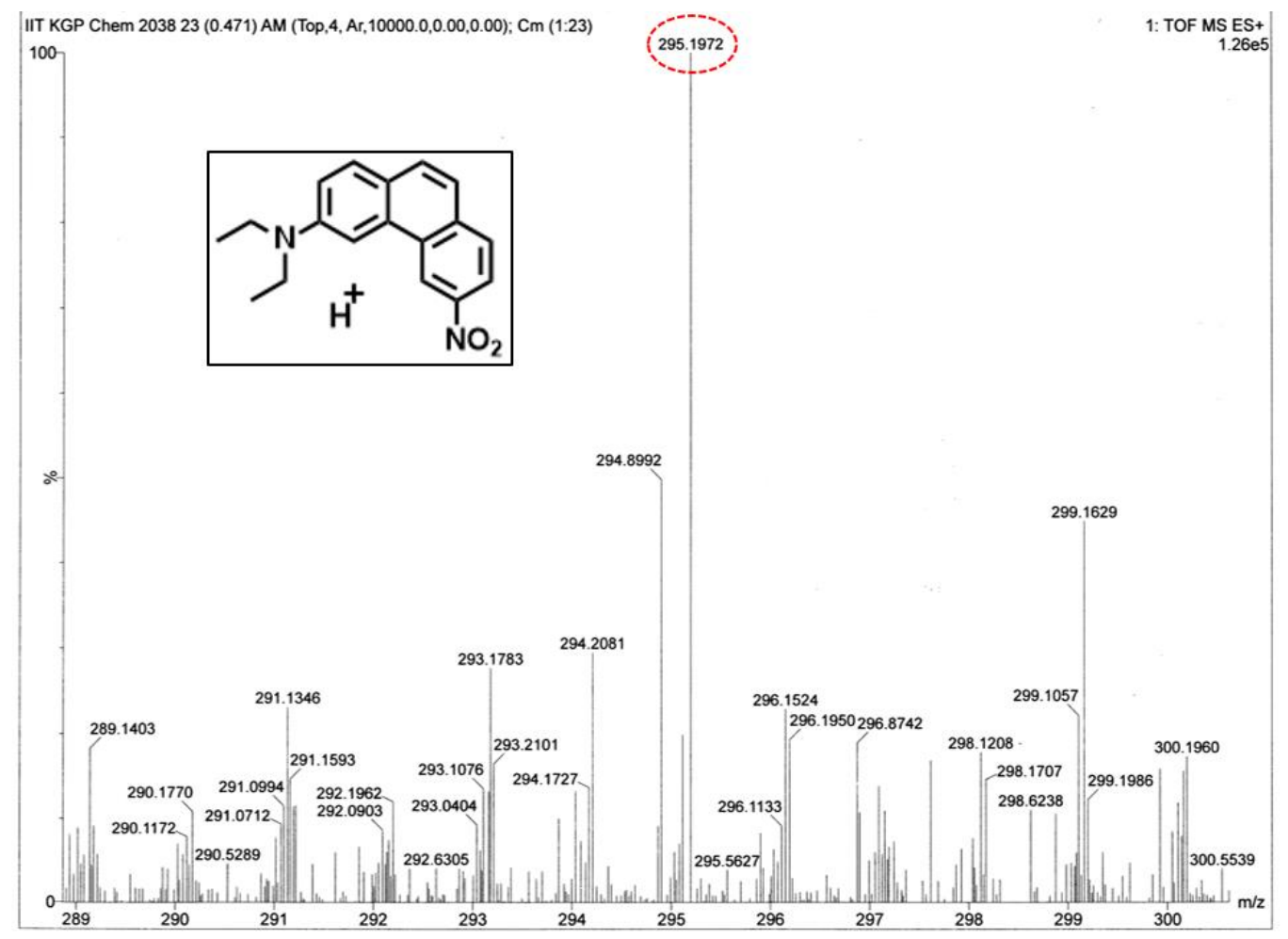

Figure S12: HRMS spectrum of photoproduct 5. 
14. Photolysis of caged stilbene 2 a monitored by ${ }^{1} \mathrm{H}$ NMR in acetonitriile-d3

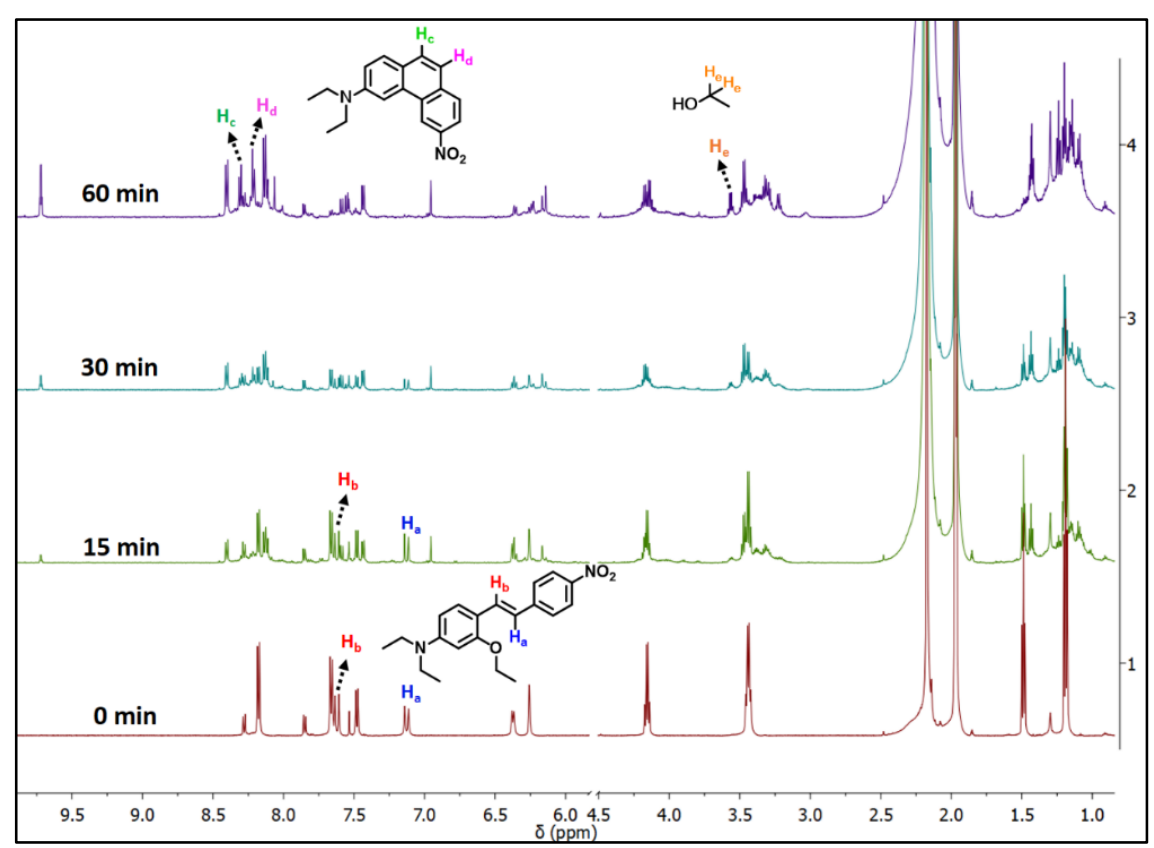

Figure S13. Photolysis of caged stilbene 2a monitored by ${ }^{1} \mathrm{H}$ NMR in acetonitriile- $\mathrm{d}_{3}$

15. ${ }^{1} \mathrm{H}$ NMR spectrum of isolated photoproduct

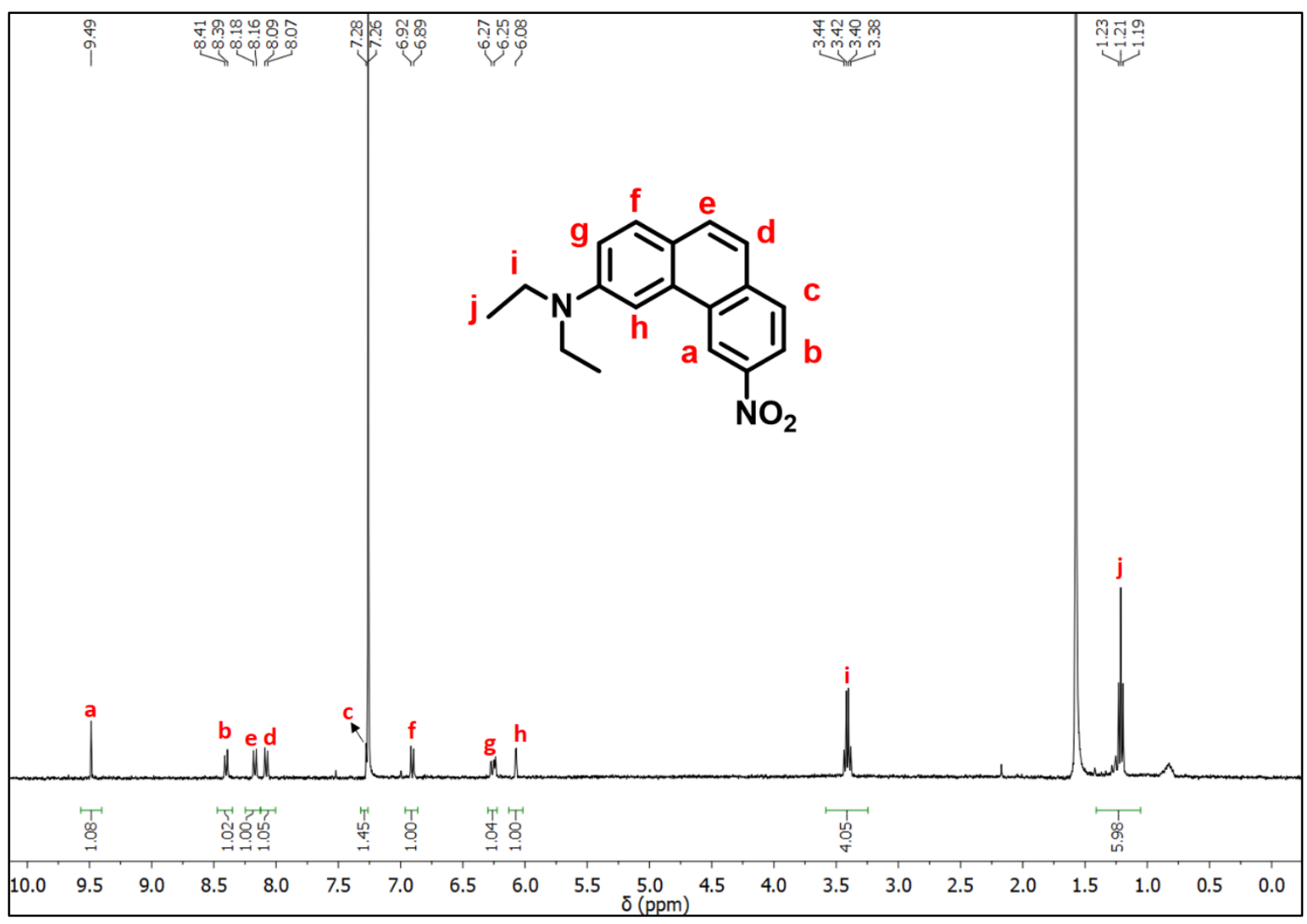

Figure S14. ${ }^{1} \mathrm{H}$ NMR spectrum of isolated photoproduct (5) (400 MHz, $\left.\mathrm{CDCl}_{3}\right)$. 
Characterisation of the photoproduct 5:

${ }^{1} \mathrm{H}$ NMR (400 MHz, Chloroform- $d$ ) $\delta 9.49(\mathrm{~s}, 1 \mathrm{H}), 8.40(\mathrm{~d}, J=8.6 \mathrm{~Hz}, 1 \mathrm{H}), 8.17(\mathrm{~d}, J=9.0$ $\mathrm{Hz}, 1 \mathrm{H}), 8.08(\mathrm{~d}, J=8.8 \mathrm{~Hz}, 1 \mathrm{H}), 7.28(\mathrm{~s}, 1 \mathrm{H}), 6.91(\mathrm{~d}, J=9.2 \mathrm{~Hz}, 1 \mathrm{H}), 6.26(\mathrm{~d}, J=8.7 \mathrm{~Hz}$, $1 \mathrm{H}), 6.08(\mathrm{~s}, 1 \mathrm{H}), 3.41(\mathrm{q}, J=7.1 \mathrm{~Hz}, 4 \mathrm{H}), 1.21(\mathrm{t}, J=7.1 \mathrm{~Hz}, 6 \mathrm{H})$. UV/Vis (acetonitrile): $\lambda_{\max }$ $(\log \varepsilon) 420 \mathrm{~nm}(4.11)$.

16. Time dependent absorbance spectra for photorelease of $2 \mathrm{c}$ in acetonitrile

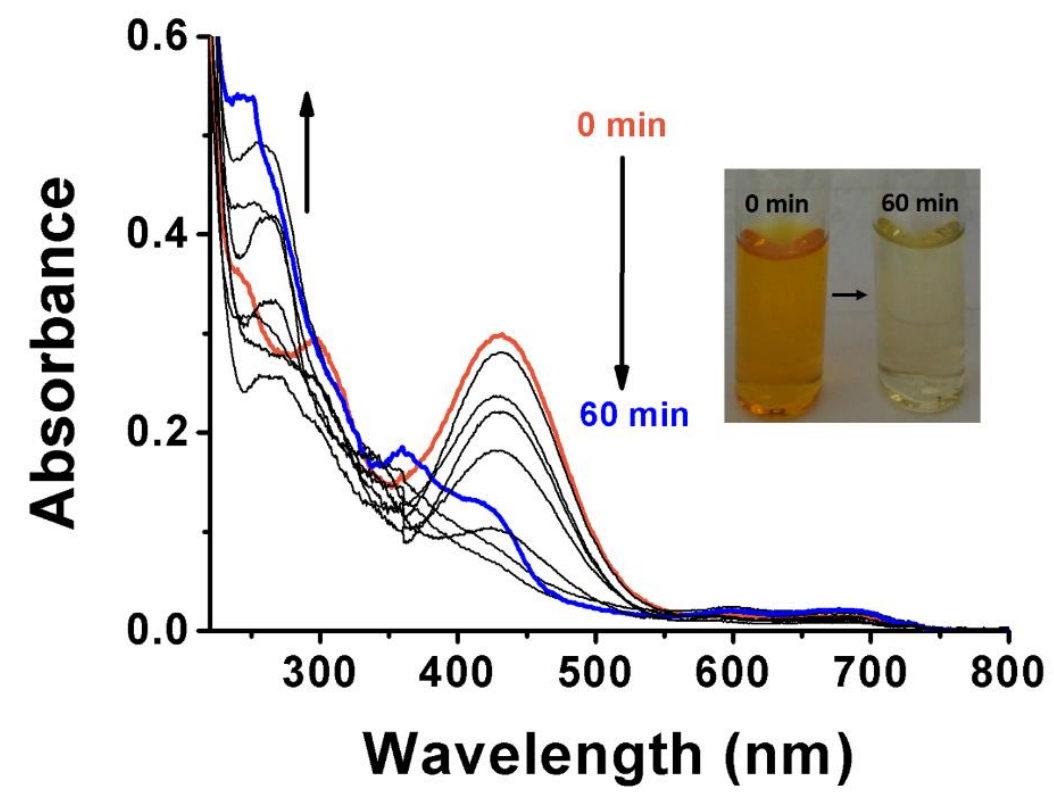

Figure S15. Time dependent absorbance spectra for photorelease of $2 \mathbf{c}$ in acetonitrile.

17. Absorbance spectra for photorelease of $2 \mathrm{c}$ in different solvents

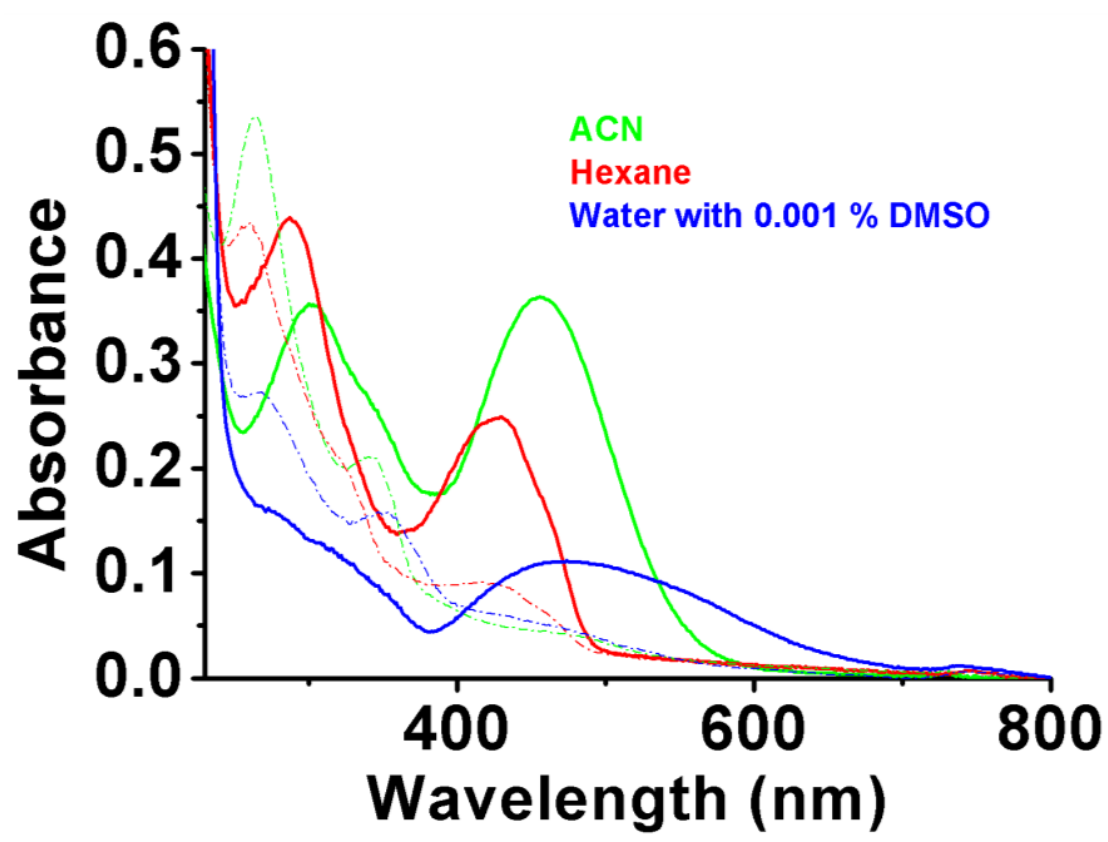

Figure S16 : Absorption spectra for photorelease of $\mathbf{2 c}$ in acetonitrile, hexane and water $(0.001$ $\%$ DMSO). Solid lines represent spectra before photolysis and dotted lines are spectra after 1 $\mathrm{h}$ photolysis. 
18. Uncaging of Anisic acid from cis caged stilbene (3d) under dark and light conditions

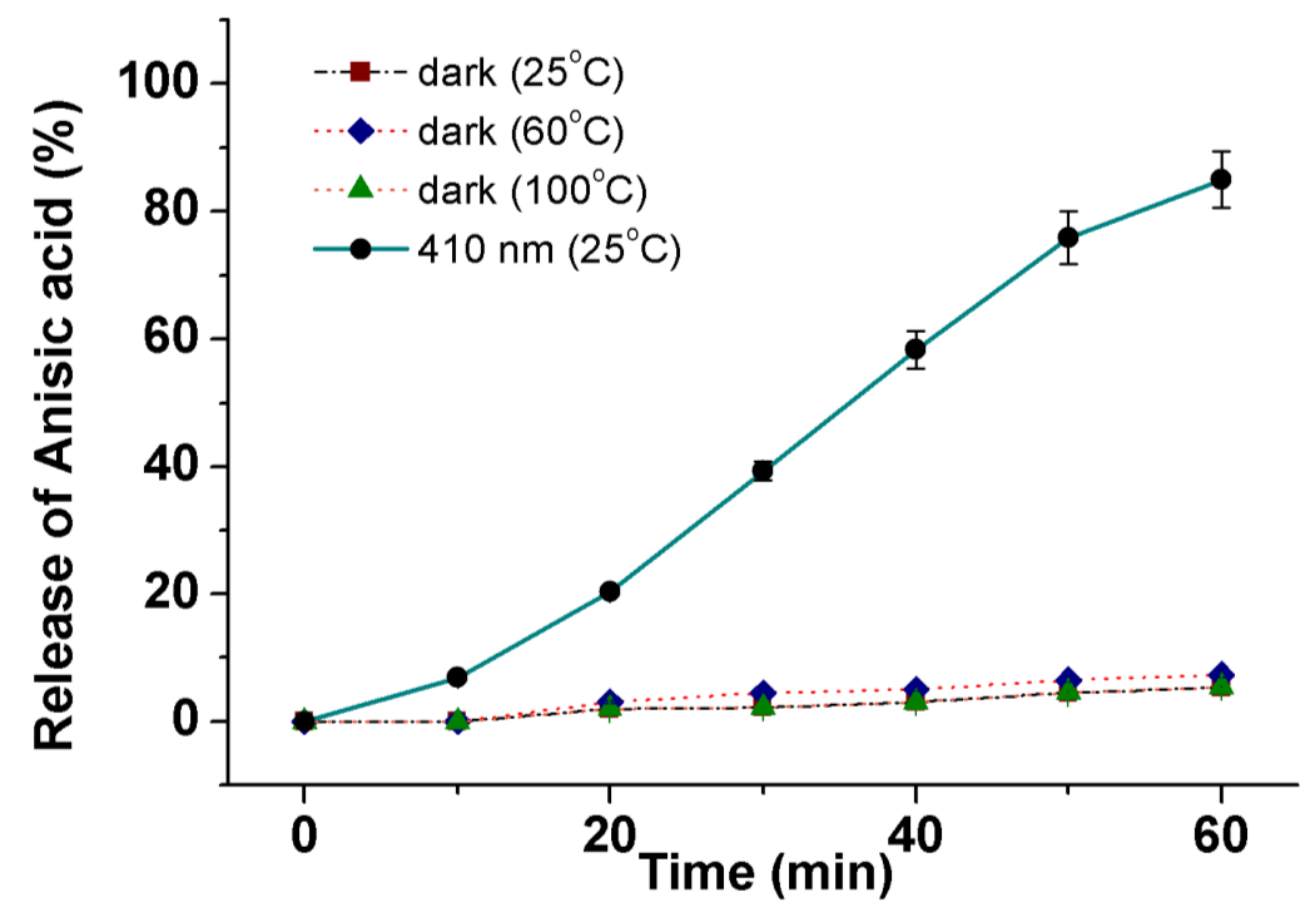

Figure S17: Percentage of Anisic acid released from 3d $\left(1 \times 10^{-4} \mathrm{M}\right)$ in acetonitrile under light $(\lambda \geq 410 \mathrm{~nm})$ and dark conditions at different temperatures. The reaction was followed by RP HPLC analysis.

19. Kinetics of the dark release step

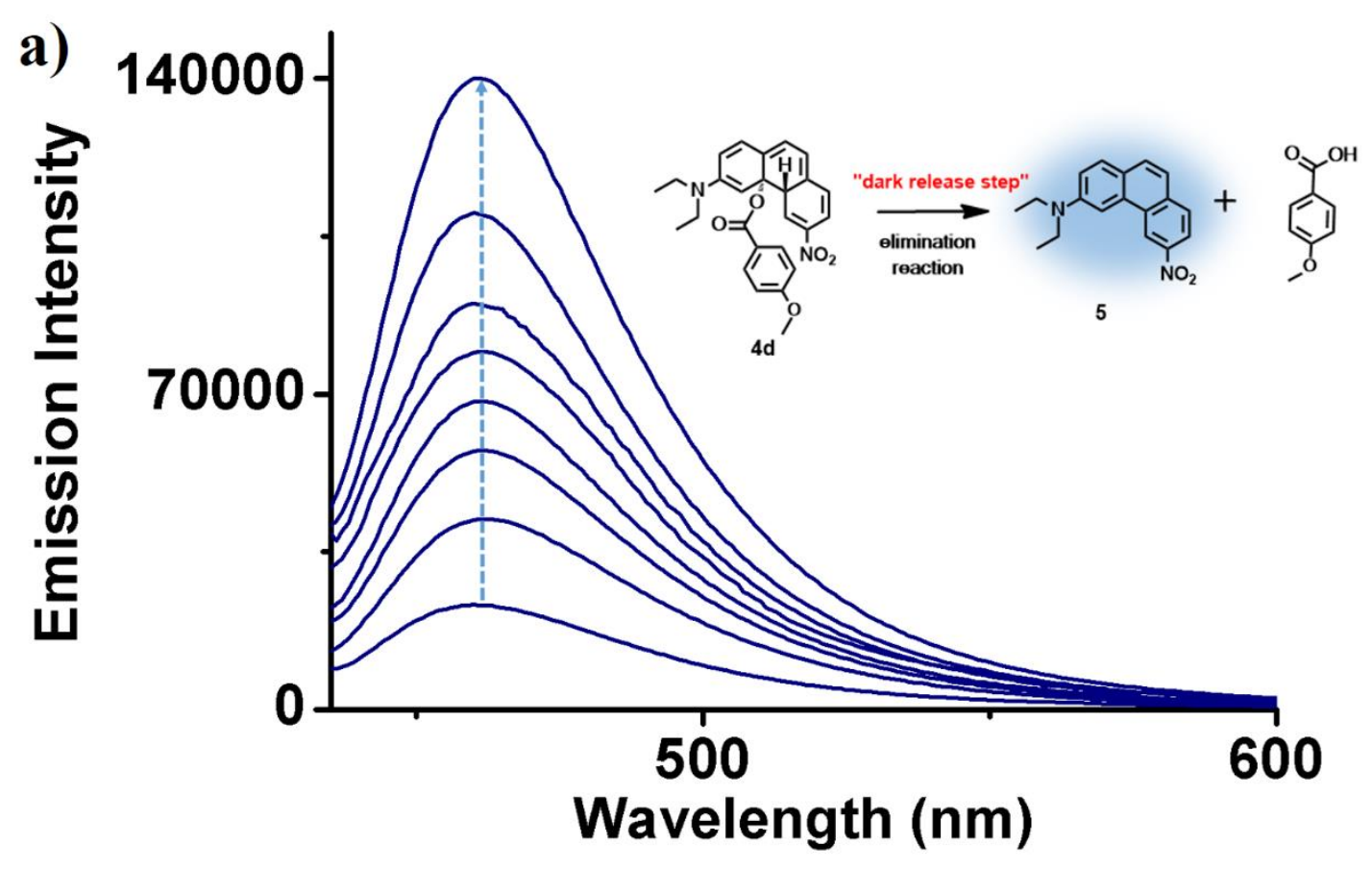




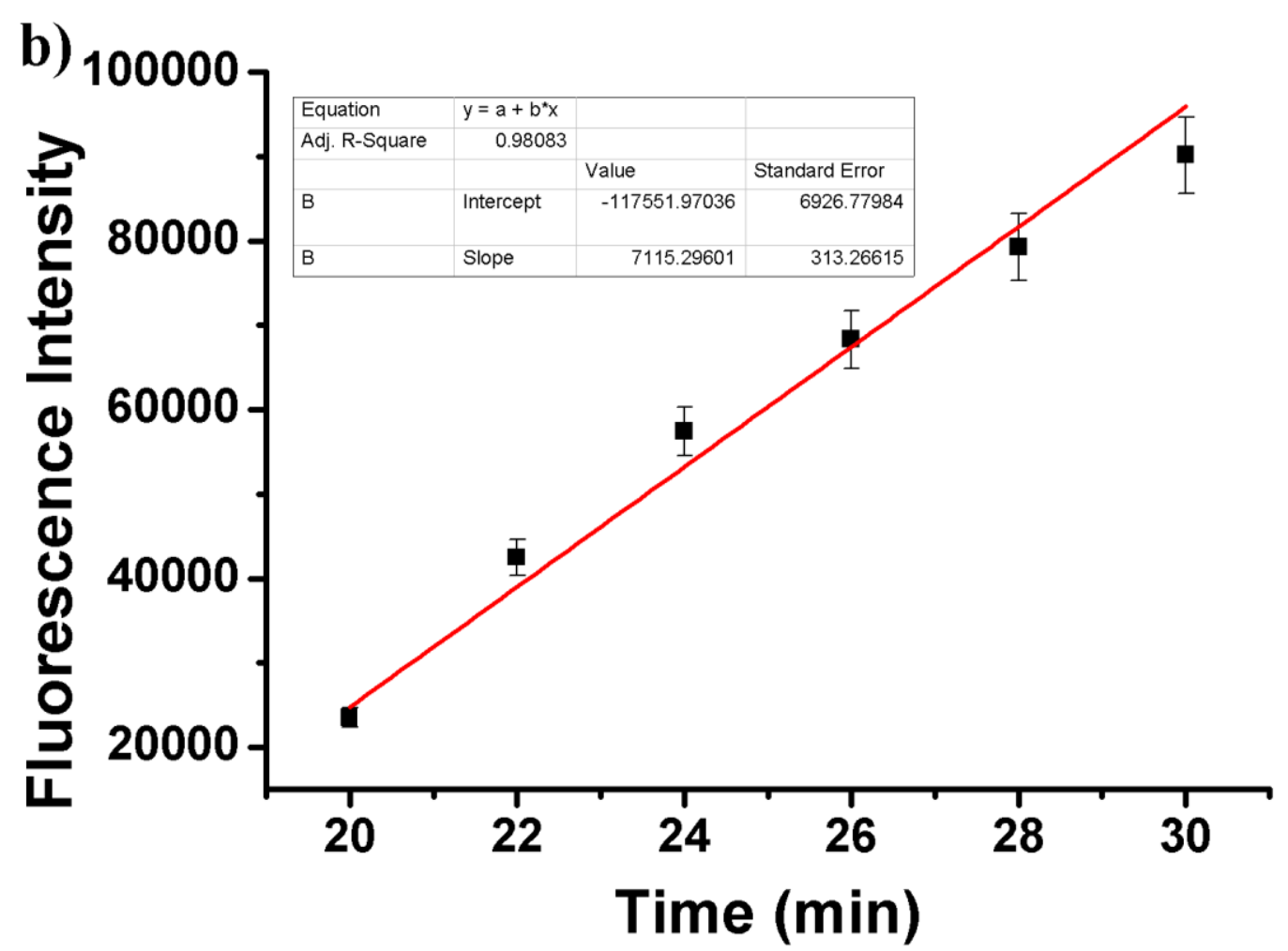

Figure S18 a) Dark release step followed by fluorescence spectroscopy with rate constant 7.1 $\mathrm{x} 10^{3} \mathrm{~s}^{-1}$. b) Kinetics of the dark release step followed by fluorescence spectroscopy.

20. Table S4: Hydrolytic stability of the caged stilbenes under dark (2a-e)

\begin{tabular}{c|c} 
Caged Stilbenes & \% depleted \\
$2 \mathrm{a}$ & 4 \\
$2 \mathrm{~b}$ & 3 \\
$2 \mathrm{c}$ & 5 \\
$2 \mathrm{~d}$ & 4 \\
$2 \mathrm{e}$ & 6
\end{tabular}


21. RP-HPLC chromatograms of drug (cbl) release from the DDS (2e)
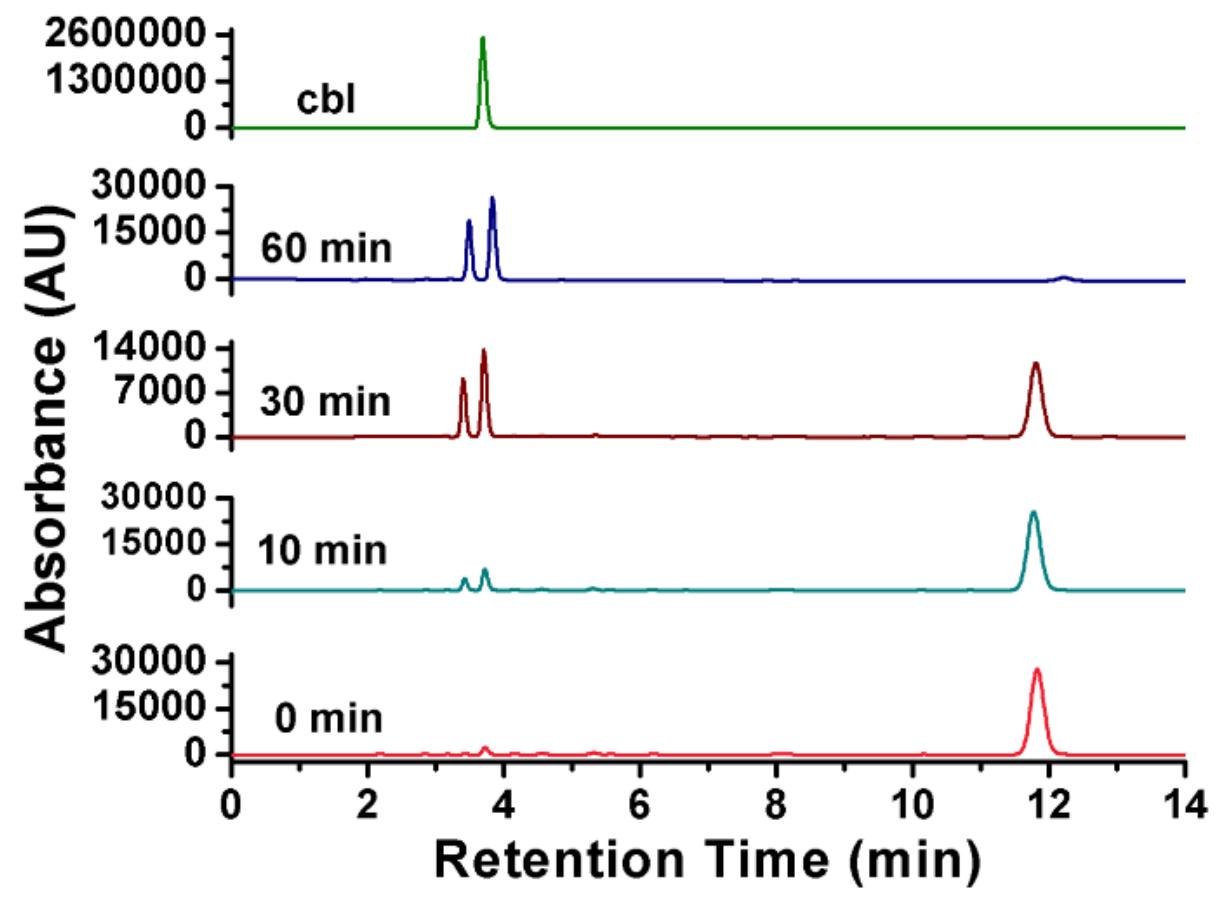

Figure S19. RP-HPLC chromatograms of the DDS (2e) at regular time intervals on irradiation with visible light $(\geq 410 \mathrm{~nm})$. AU=arbitrary units.

22. Cellular viability assay
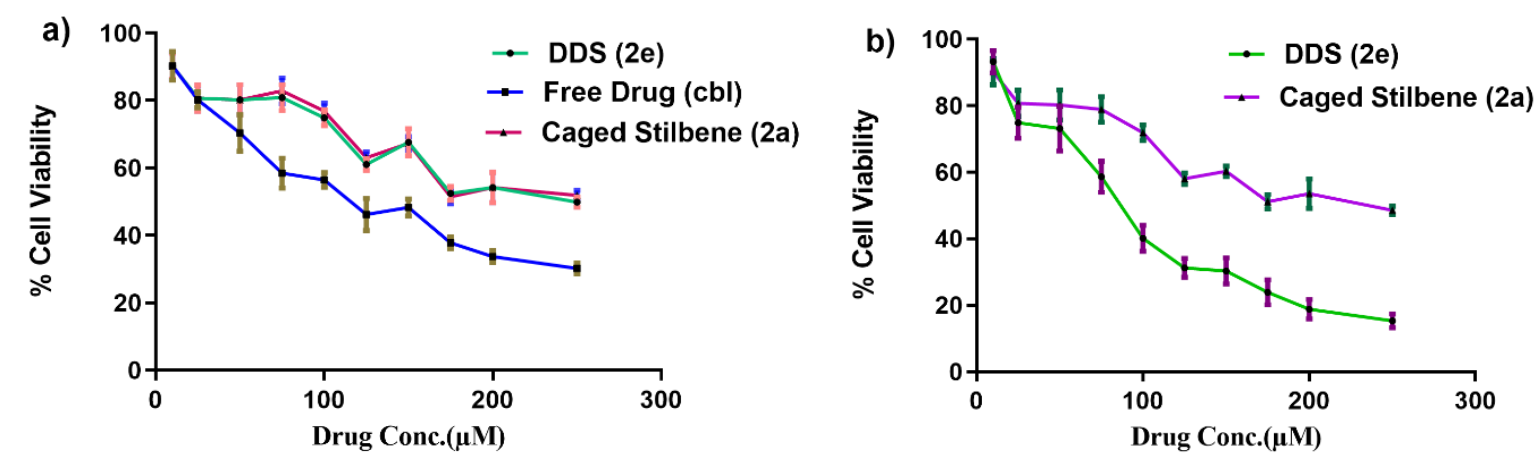

Figure S20. Cell viability assay of caged stilbene (2a), DDS (2e) and free drug in MCF-7 breast cancer cell line : (a) before photolysis, (b) after photolysis. Values are presented as mean $\pm \mathrm{SD}$.

References:

1. Mandal, S.; Ghatak, C.; Rao, V.G.; Ghosh, S.; Sarkar. N. J. Phys. Chem. C 2012, 116, $5585-5597$.

2. Reynolds, G. A.; Drexhage, K. H. Opt. Commun. 1975, 13, 222- 225. 
3. Ryan, E. T.; Xiang, T.; Johnston, K. P.; Fox, M. A. J. Phys. Chem. A 1997, 101, $1827-1835$.

4. Pal, I.; Dey, K. K.; Chaurasia, M.; Parida, S.; Das, S.; Rajesh, Y.; Sharma, K.;

Chowdhury, T.; Mandal, M. Tumor Biol. 2016, 37, 389-6402. 